\title{
CHARACTERIZATION OF FINE FRACTIONS FROM LANDFILL MINING: A REVIEW OF PREVIOUS INVESTIGATIONS
}

\author{
Juan C. Hernández Parrodi ${ }^{1,2, *}$, Daniel Höllen ${ }^{1}$ and Roland Pomberger ${ }^{1}$ \\ ${ }^{1}$ Department of Environmental and Energy Process Engineering, Montanuniversität Leoben, Franz-Josef-Straße 18, 8700 Leoben, Austria \\ ${ }^{2}$ NEW-MNE project, Renewi Belgium SA/NV, Gerard Mercatorstraat 8, 3920 Lommel, Belgium
}

Article Info:
Received:
7 February 2018
Revised:
4 April 2018
Accepted:
11 June 2018
Available online:
30 June 2018
Keywords:
Landfill mining
Enhanced landfill mining
Waste characterization
Fine fractions
Fines

Article Info:

7 February 2018

11 June 2018

Available online:

30 June 2018

Keywords:

Enhanced landfill mining

Fine fraction

\section{ABSTRACT}

Several landfill mining (LFM) studies have been carried out in recent years all around the world. From these studies qualitative and quantitative information regarding the composition and characteristics of the different fractions excavated from landfills has been obtained. This information comprises data from various landfill sites around the globe from which useful correlations for future LFM projects can be identified. Of particular interest to this paper is the information regarding the fine fractions, which represent to this day a crucial obstacle in the implementation of LFM and enhanced landfill mining (ELFM). The fine fractions make up a considerable portion of the total amount of waste disposed of in landfills. Depending on the particle size chosen as upper limit to define the fines fraction, the portion of this fraction can be as high as $40-80$ wt.\% of the total excavated waste. These fractions consist of decomposed organic substances, e.g. humic substances, partly weathered mineral waste, e.g. sand, brick fragments, concrete, but also of fine metal particles, especially non-ferrous metals, and still a significant amount of plastics, paper and other calorific fractions. However, although calorific fractions might be used for energy recovery and inorganic fractions for material (especially metal) recovery, current LFM studies are discarding the fine fraction due to lacking or too expensive processing routes. Therefore, it is of critical interest to LFM and ELFM projects to reduce the particle size down to which the excavated material can be processed. This paper, which was elaborated within the framework of the EU Training Network for Resource Recovery through Enhanced Landfill Mining - NEW-MINE, aims to review the obtained data from different LFM studies from municipal solid waste (MSW) landfills, concerning the fines fraction, in order to identify key aspects to be taken into consideration while designing the processing approach in future LFM and ELFM investigations.

\section{INTRODUCTION}

Since its commencement, in 1953 at the Hirya landfill in Israel (Savage, Golueke, \& Von Stein, 1993), the focus of LFM has been evolving, incorporating different drivers and objectives to its original purpose over the years. To this day, some common drivers of LFM projects have been: material recovery (recyclable and reusable materials), land reclamation, landfill capacity regain, pollution mitigation, landfill remediation, removal of deposits obstructing urban development, production of alternative fuels, aftercare and closure costs reduction, enabling the operation of regional MSW incinerators at full capacity, reuse of already available landfill infrastructure, simplification of the permitting process, among others (Hull, Krogmann, \& Strom, 2005; Krook, Svensson, \& Eklund, 2012).

Moreover, a holistic concept, ELFM, has been developed during this decade. This approach envisages the combined and integrated waste valorization of old and future waste deposits as both materials (Waste-to-Material, WtM) and energy (Waste-to-Energy, WtE); while respecting most stringent ecological and social criteria (Jones, Geysen, Rossy, \& Bienge, 2010).

Since landfills were for decades the sole disposal solution for all types of waste with any segregation, they represent a heterogeneous source of materials (Kaartinen, Sormunen, \& Rintala, 2013). Previous investigations made by Krook et al., 2012; Cossu, Motzo, \& Laudadio, 1995, Kaartinen et al., 2013; Prechthai, Padmasri, \& Visvanathan, 2008; Quaghebeur et al., 2013; Zhao, Song, Huang, Song, \& Li, 2007 report that landfill-mined waste normally consists of 20-30 wt.\% combustible materials, 50-60 wt.\% fine-grained degraded matter, 10 wt.\% inert materials and a small percentage of metals. For further references predating year 2011, a broad worldwide overview of over 60 LFM projects 
and the rough composition of landfilled waste from over 20 landfill dismantling and exploratory drilling projects can be consulted in the work made by Bockreis \& Knapp, 2011.

A more detailed material composition (Van Vossen \& Prent, 2011), obtained from information found in literature of 60 landfill mining projects, plus the outcomes of most recent investigations (after year 2011) are presented in Table 1.

In this information (Table 1) it can be noticed that the fine fractions (referred sometimes as "soil", "soil-like" or "soil-type" fractions, due to their appearance, organic mat- ter and mineral contents and relatively homogeneous composition compared to the coarser fractions) are commonly to a great extent the largest fraction of the whole excavated amount in a LFM project. These fractions typically contain mainly degraded garden and food materials (Quaghebeur et al., 2013). This degradation process can be compared to the natural humification process during soil formation. Since the US EPA reported that around $75 \%$ of the LFM material corresponds to mineral landfill liners and degraded organic waste (Landfill Reclamation, 1997), a comparison

TABLE 1: Material composition of excavated waste from previous LFM investigations.

\begin{tabular}{|c|c|c|c|c|c|c|}
\hline Parameter & $\begin{array}{l}\text { Van Vossen and } \\
\text { Prent, } 2011 \\
\text { (various countries) }\end{array}$ & $\begin{array}{c}\text { Jani et al., } 2016 \\
\text { (Högbytorp, } \\
\text { Sweden) }\end{array}$ & $\begin{array}{l}\text { Kaartinen et al., } \\
2013 \\
\text { (Kuopio, Finland) }\end{array}$ & $\begin{array}{l}\text { Bhatnagar et al., } \\
2017 \\
\text { (Kudjape, Estonia) }\end{array}$ & $\begin{array}{l}\text { Wolfsberger et } \\
\text { al., } 2015 \text { (Lower } \\
\text { Austria, Austria) }\end{array}$ & $\begin{array}{l}\text { Quaghebeur et al., } \\
2013 \\
\text { (REMO, Belgium) }\end{array}$ \\
\hline $\begin{array}{l}\text { Type of waste } \\
\text { disposed of }\end{array}$ & Various & $M S W+C \& D$ & MSW & MSW & MSW & MSW \\
\hline Age of waste [a] & Various & 5 & $5-10$ & 10 & $13-20$ & $14-29$ \\
\hline $\begin{array}{l}\text { Fraction(s) con- } \\
\text { sidered }\end{array}$ & All & $10-40 \mathrm{~mm}$ & All & All & All & All \\
\hline $\begin{array}{l}\text { Average moisture } \\
\text { content }\end{array}$ & - & - & - & - & $29.0-55.0 \%$ & $53.0-68.0 \%$ \\
\hline $\begin{array}{l}\text { Fines / Sorting } \\
\text { residue / Soil-type } \\
\text { material }\end{array}$ & $54.8 \%$ & $27.3 \%$ & $50.0-54.0 \%$ & $28.7 \%$ & $47.0 \%$ & $44.0 \pm 12.0 \%$ \\
\hline Stones & $2.5 \%$ & $28.1 \%$ & - & $17.5 \%$ & - & - \\
\hline Minerals / Inert & $5.8 \%$ & - & - & - & $6.0 \%$ & $10.0 \pm 6.0 \%$ \\
\hline$C \& D$ & $9.0 \%$ & - & - & - & - & - \\
\hline Limestone & - & $4.8 \%$ & - & - & - & - \\
\hline Asphalt & - & $3.2 \%$ & - & - & - & - \\
\hline Glass / Ceramics & $1.1 \%$ & $5.6 \%$ & - & $4.6 \%$ & $1.0 \%$ & $1.3 \pm 0.8 \%$ \\
\hline Plastics & $4.7 \%$ & - & $23.0 \%$ & $22.4 \%$ & $18.0 \%$ & $17.0 \pm 10.0 \%$ \\
\hline Soft plastics & - & $0.7 \%$ & - & - & - & - \\
\hline $\begin{array}{l}\text { Other plastic / } \\
\text { Composites }\end{array}$ & - & $6.8 \%$ & - & - & $4.0 \%$ & - \\
\hline $\begin{array}{l}\text { Organic / Kitchen } \\
\text { waste }\end{array}$ & $5.3 \%$ & - & - & - & - & - \\
\hline $\begin{array}{l}\text { Paper \& cardboard } \\
\text { / PPC }\end{array}$ & $5.3 \%$ & - & $4.0-8.0 \%$ & $5.1 \%$ & $3.0 \%$ & $7.5 \pm 6.0 \%$ \\
\hline Paper & - & $4.5 \%$ & - & - & - & - \\
\hline Wood & $3.5 \%$ & $15.2 \%$ & $6.0-7.0 \%$ & $4.7 \%$ & - & $6.7 \pm 5.0 \%$ \\
\hline Textiles & $1.6 \%$ & $2.7 \%$ & $7.0 \%$ & - & $6.0 \%$ & $6.8 \pm 6.0 \%$ \\
\hline Leather & $1.6 \%$ & - & - & - & - & - \\
\hline Rubber & - & $0.2 \%$ & - & - & - & - \\
\hline $\begin{array}{l}\text { Wood, leather and } \\
\text { rubber }\end{array}$ & - & - & - & - & $9.0 \%$ & - \\
\hline Total metals & $2.0 \%$ & - & $3.0-4.0 \%$ & $3.1 \%$ & $5.0 \%$ & $2.8 \pm 1.0 \%$ \\
\hline Fe metals & - & $0.5 \%$ & - & - & - & - \\
\hline Non-Fe metals & - & $0.5 \%$ & - & - & - & - \\
\hline Other / Rest & $2.6 \%$ & - & $2.0 \%$ & $13.4 \%$ & $1.0 \%$ & - \\
\hline Non-MSW & $0.3 \%$ & - & - & - & - & - \\
\hline Notes: & \multicolumn{6}{|c|}{$\begin{array}{l}\text { Information organized according to age of waste } \\
\text { Totals may not add exactly } 100 \% \text { due to figures' rounding } \\
\text { Figures have weight and wet basis } \\
\text { MSW - Municipal solid waste } \\
C \& D \text { - Construction and demolition waste } \\
\text { PPC - Paper, paperboard and cardboard }\end{array}$} \\
\hline
\end{tabular}


to natural soils which also contain fine-grained mineral and organic materials can be drawn. However, the different genesis of the fine fractions in landfills and of soils, and the lack of separation of the fine fractions from other materials in the landfill, do not allow addressing the fine fractions from landfills as soils.

Fine fractions (frequently defined as material with a particle size $<60 \mathrm{~mm}$ to $<10 \mathrm{~mm}$ ) account for $40-80 \mathrm{wt} . \%$ of the mined material in previous studies (Hogland, 2002; Masi, Caniani, Grieco, Lioi, \& Mancini, 2014; Kaartinen et al., 2013; Kurian, Esakku, Palanivelu, \& Selvam, 2003; Rettenberger, 2009; Hull et al., 2005; Mönkäre, Palmroth, \& Rintala, 2016; Quaghebeur et al., 2013; Maul \& Pretz, 2016; Van Vossen \& Prent, 2011; Wiemer, Bartsch, \& Schmeisky, 2009; Wolfsberger et al., 2015). Therefore, regardless of the particle size used to define the fine fractions, its quantity will always be an important factor to be considered in LFM and ELFM projects.

The main purpose of the present review is to gather information regarding the fine fractions of previous LFM investigations, in order to identify their composition and properties, so that the possibility of material and energy recovery from these fractions can be assessed in forthcoming research, as well as to identify key aspects to be taken into account while designing the processing approach in future LFM and ELFM investigations.

\section{MATERIALS AND METHODS}

The present study comprises a review of several previous LFM investigations found in scientific literature. The main focus of this review paper is on the material characterization of the fine fractions. The scope envisages scientific papers published in international peer-reviewed journals, as well as a minor amount of other review papers and international conference proceedings, books, guidelines, standards and legislation.

\section{REVIEW AND DISCUSSION}

There have been plenty of LFM projects and investigations carried out up to now; nevertheless, not much attention has been paid to the fine fractions in terms of their potential for material recovery, alternative fuels production and possible alternative uses (e.g. as cover layer in operating landfills, as filling material for leveling purposes or the construction of embankments, as soil improver for growing nonedible crops, etc.). In most LFM projects recycling has been restricted to the coarse fractions, while the fine fractions have been re-directed to the landfill with poor or no treatment beforehand, mainly due to technical and economic challenges, despite their recovery potential (Bhatnagar et al., 2017; Münnich, Fricke, Wanka, \& Zeiner, 2013).

According to previous investigations (Kaartinen et al., 2013; Mönkäre et al., 2016; Wolfsberger et al., 2015) the amount of fines to be obtained in a LFM project mostly depends on the excavation procedure, the age of the waste and the selected cut-off diameter to define a certain particle size as upper limit for the fine fractions. For example: (i) the implementation of borehole sampling via drilling activities can increase the amount of fine fractions in the samples, (ii) the amount of fine fractions has been found to raise with age in some investigations and (iii) the amount of material passing the screen tends to increase with the increase in size of the cut-off diameter of the screen. However, these factors might be correlated with one another and each of them can increase or decrease the amount of fine fractions by itself. Therefore, the specific setup employed in a particular LFM project is to be analyzed in a single-case base, in order to determine the overall effect of these factors on the total amount of fine fractions to be obtained.

Additionally, the characteristics of the fine fractions of landfill-mined material can be influenced by the chosen processing, e. g. sieve size affects utilization and disposal methods of the sieved materials, as it has been observed that the methane potential rises with the increase of particle size (Mönkäre et al., 2016). Moreover, the amount of fine fractions increases with time due to the decomposition processes (Jani et al., 2016). Long disposal time leads to degradation processes of the organic matter, which leads to a higher amount of fines (Maul \& Pretz, 2016).

Because of the lack of economic value, the characterization properties of the fine fractions have not been thoroughly investigated (Mönkäre et al., 2016). Nonetheless, in order to evaluate the specific recycling potential of a landfill, adequate and proper quantitative and qualitative characterizations of the disposed waste are to be performed (Prechthai et al., 2008).

It is important to point out that much care needs to be taken when comparing information between different investigations directly, since there are many factors, such as; characterization conditions and procedures, laboratory analyses and followed standards, age of the waste material, defined particle size for the fines fraction, among others, that might play an important role during their execution and may differ significantly from investigation to investigation. The implementation of different approaches for the material characterization of waste remains to be one of the crucial challenges for the elaboration of comparable and accurate compiled studies.

\subsection{Material composition}

In this paper, material composition refers to the kind of material, e.g. "plastic" or "textiles", whereas chemical composition refers to the elemental composition and mineralogical composition to the phase composition. On the basis of the result of previous studies on the material composition of the fine fractions, of excavated waste from landfill, some tendencies can be recognized. Table 2 shows a compilation of these studies and their reported results. Some clear trends that can be noticed, apart from the already stated clear dominance of the amount of fines over the total, are the considerable amounts, in some cases, of inert materials (mainly stones and glass), plastics, textiles, paper and metals present in these fractions. This information allows grouping the sub-fractions that constitute the fine fractions in to major constituents, which are degraded organic and mineral materials, and minor constituents, which are plastics, textiles, metals paper and 
TABLE 2: Material composition of excavated fine fractions from previous LFM investigations.

\begin{tabular}{|c|c|c|c|c|c|c|}
\hline Parameter & $\begin{array}{l}\text { (Filborna, Sweden) } \\
\text { in Kurian et al., } \\
2003 \\
\end{array}$ & $\begin{array}{l}\text { Wolfsberger et } \\
\text { al., } 2015 \text { (Lower } \\
\text { Austria, Austria) }\end{array}$ & $\begin{array}{l}\text { Hull et al., } 2005 \\
\text { (BCRRC, USA) }\end{array}$ & $\begin{array}{l}\text { Kurian et al., } 2003 \\
\text { (Perungudi, India) }\end{array}$ & $\begin{array}{l}\text { Kurian et al., } 2003 \\
\text { (Kodungaiyur, India) }\end{array}$ & $\begin{array}{l}\text { (Deonar, India) in } \\
\text { Kurian et al., } 2003\end{array}$ \\
\hline $\begin{array}{l}\text { Type of waste } \\
\text { disposed of }\end{array}$ & MSW & MSW & $M S W+C \& D+I W$ & MSW & MSW & MSW \\
\hline Age of waste [a] & - & $13-20$ & $1-11$ & $0-10$ & 10 & - \\
\hline Particle size [mm] & $<40$ & $<40$ & $<25.4$ & $<20$ & $<20$ & $<8$ \\
\hline $\begin{array}{l}\text { Amount of fines } \\
\text { from the whole }\end{array}$ & $65.7 \%$ & $68.0 \%$ & $\geq 50 \%$ & $58.9 \%$ & $32.3 \%$ & $34.6 \%$ \\
\hline Sorting residue & - & $65.6 \%$ & - & - & - & - \\
\hline Stones & $19.0 \%$ & - & - & $18.5 \%$ & $28.3 \%$ & $31.5 \%$ \\
\hline Minerals / Inert & - & $6.6 \%$ & - & - & - & - \\
\hline Glass & $0.5 \%$ & $1.4 \%$ & - & $0.8 \%$ & $0.4 \%$ & - \\
\hline Wood & - & - & $8.5-11.7 \%$ & - & - & - \\
\hline $\begin{array}{l}\text { Wood, leather, } \\
\text { rubber }\end{array}$ & $15.7 \%$ & $5.9 \%$ & - & $26.1 \%$ & $1.0 \%$ & $1.2 \%$ \\
\hline Textiles / Rubber & $4.5 \%$ & $1.9 \%$ & $5.4-6.8 \%$ & $2.3 \%$ & $0.6 \%$ & - \\
\hline Plastics & $18.1 \%$ & $11.6 \%$ & $10.5-19.5 \%$ & $11.0 \%$ & $1.9 \%$ & $1.5 \%$ \\
\hline Composites & - & $1.0 \%$ & - & - & - & - \\
\hline PPC & - & $3.0 \%$ & - & - & - & - \\
\hline Paper & - & - & $6.8-14.4 \%$ & - & - & - \\
\hline Cardboard & - & - & $4.6-14.9 \%$ & - & - & - \\
\hline Total metals & $7.9 \%$ & $1.9 \%$ & - & $0.2 \%$ & $0.1 \%$ & $0.4 \%$ \\
\hline Fe metals & - & - & $5.5-12.6 \%$ & - & - & - \\
\hline Others & - & $1.1 \%$ & - & - & - & - \\
\hline $\begin{array}{l}\text { Problematic sub- } \\
\text { stances }\end{array}$ & - & $0.1 \%$ & - & - & - & - \\
\hline Notes: & $\begin{array}{l}\text { Information organize } \\
\text { Totals may not add } \\
\text { Figures have weight } \\
\text { MSW - Municipal soli } \\
\text { C\&D - Construction a } \\
\text { IW - Industrial waste } \\
\text { PPC - Paper, paperbo }\end{array}$ & $\begin{array}{l}\text { according to particl } \\
\text { ctly } 100 \% \text { due to fig } \\
d \text { wet basis } \\
\text { waste } \\
\text { I demolition waste } \\
\text { d and cardboard }\end{array}$ & ize & & & \\
\hline
\end{tabular}

cardboard, among others. Below, particular tendencies and aspects that have been found in former investigations are discussed.

The fine fractions have been found aesthetically unpleasant due to the presence of non-soil materials, such as plastic and paper flakes and broken glass (Hull et al., 2005). Zhao et al., 2007 reported that the fine fractions showed similarities to black soil and suggested, therefore, a use for green construction, organic fertilizer or as bioreactor media for biological treatment of leachate. Bhatnagar et al., 2017 identified the fraction $<40 \mathrm{~mm}$ as composed of $22 \mathrm{wt} . \%$ inert materials (glass and stones), $5.4 \mathrm{wt} . \%$ biodegradables (paper and wood), 5 wt.\% combustibles (mix of plastic textile and rubber), 1 wt.\% metals (Fe, $\mathrm{Cu}$ and $\mathrm{Al}$ ) and a larger amount of non-identified material. An amount of about $20 \mathrm{wt}$.\% DM of the fraction < $25.4 \mathrm{~mm}$ was reported by Hull et al., 2005 to be accounted for the sum of metal, plastic, glass, textile/rubber/leather and stone/brick/concrete materials.

According to the findings of Prechthai et al., 2008 and Masi et al., 2014, the fractions $<25 \mathrm{~mm}$ and $<10 \mathrm{~mm}$, respectively, were mainly composed of organic matter and fine-grained mineral matter, pieces of wood, metals, glass and plastics. The fraction $0.425-6.3 \mathrm{~mm}$ was mainly constituted by degraded organic matter mixed with broken glass and ceramics, whereas the fraction $<0.425 \mathrm{~mm}$ was composed mainly of mineral particles (Jain, Kim, \& Townsend, 2005). A soil-like mixture of minerals and organic matter was the most abundant material in the fraction $<20 \mathrm{~mm}$ identified by manual sorting reported by Kaartinen et al., 2013; this fraction was particularly dominant within the fraction $<4 \mathrm{~mm}$.

The high content of fine-grained aggregates of mineral and organic particles in the aged MSW is likely the result of the daily covering soil (Chen, Guan, Liu, Zhou, \& Zhu, 2010) and the humification of organic matter in fresh MSW. Organic waste normally degrades and cannot be identified after some years of being landfilled (Quaghebeur et al., 2013), since the material is gradually transformed into humus. Humus is the stable state reached by organic matter after being degraded down to the point where organic matter resists further degradation and constitutes one of the main components of soil, together with liquids, gases, minerals and living microorganisms (Stevenson, 1994). 
Prechthai et al., 2008 found no significant variation in waste-type composition of waste among different sampling locations within one landfill. However, he reported variations in the composition of the fine fractions along the vertical profile, suggesting a variation depending on the degree of biodegradation of waste over time in the dumpsite. Changes regarding the content of individual fractions over time were also observed by Chen et al., 2010; Hull et al., 2005; Kaartinen et al., 2013; Quaghebeur et al., 2013; Sormunen, Laurila, \& Rintala, 2013, where the mass fractions of paper and cardboard, textiles and wood were lower in older wastes. This was also the case for Jain et al., 2005, where the lower percentage of paper found in samples of an older part of the landfill than in the more recent one suggest the decomposition of paper over time. The quantity of paper-cardboard in excavated waste seems to be a useful parameter regarding the stabilization state of the material that can be easily determined on site (Francois, Feuillade, Skhiri, Lagier, \& Matejka, 2006).

Further data on the material composition of the fine fractions shows that the amount of degradable components decreased over time, while the amount of degraded components increased up to $60 \mathrm{wt} \%$ (Francois et al., 2006). Such changes can be also attributed to the composition differences of the landfilled waste due to waste management systems, legislation, changes in the consumption and production trends during the landfilling lapse (Quaghebeur et al., 2013; Spooren, Nielsen, Quaghebeur, \& Tielemans, 2012).

The data on the amount of plastic, metal, glass and inert materials did not present a significant variation in time, matching with the expected behavior for slow- or non-biodegradable components (Francois et al., 2006). Plastics recovered from landfills show similar properties to those of plastics from MSW and other secondary plastics (Maul \& Pretz, 2016).

Therefore, it can be concluded from previous studies that the amount of biodegradable materials, from the initial quantity, in landfill sites tends to decrease with time, while the amount of slow- and non-biodegradable materials tends to remain without high variations.

According to Wolfsberger et al., 2015 the amount of recyclables and materials for energy recovery in the fine fractions ( $<40 \mathrm{~mm}$ ) was significantly lower than in the coarse fractions, identified around $33 \mathrm{wt} . \%$ for the fine fraction. This value, despite being lower than for the coarse fractions, represents an interesting amount of material due to the fact that the fine fractions make up most of the excavated material. For instance, according to Bhatnagar et al., 2017 , it would be possible to obtain $23 \%$ revenue, with respect to the total income from material recovery, via individual materials from the fraction $<40 \mathrm{~mm}$.

Quaghebeur et al., 2013 reports that for certain waste fractions (i.e. metals, plastics, glass/ceramics, stones and textile) the amount found in the excavated material was comparable to the amount originally present in the waste when initially landfilled. Therefore, records with regard to the composition of fresh waste sent to a landfill over time can be a good source of information to estimate the composition of the disposed material at the site; with exception of biologically degradable materials, especially biowaste, followed by paper and paperboard, which degrade over time (Quaghebeur et al., 2013).

The previous data suggest that the fine fractions might result interesting as source of potentially recoverable materials as metals, plastics and soil-like material, as well as a source of inert materials like sand, glass and ceramics. However, when the quality of paper and cardboard, plastics, textiles and wood (calorific fractions in general) recovered from a landfill is too low or when concentrations of specific compounds, whose amounts are restricted in certain recycling routes are exceeded, waste-to-energy could be the most suitable valorization path (Quaghebeur et al., 2013). Nevertheless, there are also limit values for certain pollutants that apply to WtE and need to be taken into account. For example, an Austrian investigation accounts for a case in which several calorific fractions from LFM material did not meet the limit values applicable in Austria (Wolfsberger et al., 2015). For instance, washing of plastics from LFM reduced the contents of most heavy metals, but not of antimony ( $\mathrm{Sb}$ ) which was incorporated into the polymer (Liebetegger, 2015).

\subsection{Particle size distribution}

Table 3 gives an overview of the results on the particle size distribution of different studies: for most of the studies, the biggest amount of material belongs to the fine fractions, followed by the coarse fractions and the intermediate fractions. Logically, their amounts will depend mainly on the set particle size for the sieving process, but, however, most of the reviewed previous investigations have shown a consistent dominance of fractions $<40 \mathrm{~mm}$ upon the coarser fractions. Information of this kind is difficult to compare, since same particle sizes for the sieving of the excavated material are hardly used in different investigations.

A study on the physico-chemical characteristics of landfilled municipal solid waste of various ages (3, 8, 20 and 30 years old) at four different sites realized by Francois et al., 2006, shows that the particle size distribution of the waste (considering materials $\geq 100 \mathrm{~mm}$ as coarse fraction, materials $<100 \mathrm{~mm}$ but $>=20 \mathrm{~mm}$ as middle fraction and materials $<20 \mathrm{~mm}$ as fine fraction) changes from predominantly coarse fraction (approx. 50 wt.\%) for 3 years old waste to mainly fine and middle fractions for 30 years old waste (approx. 46 wt. $\%$ and 40 wt.\%, respectively). The data obtained from the time in between, 8 and 20 years old, show a clear gradual amount reduction of the coarse fraction, as well as a clear gradual amount increase of the fine fraction. The data for the middle fraction shows some fluctuation over time, as it would be logically expected.

Landfill mining tests carried out at a MSW landfill in Sweden by (Hogland, Marques, \& Nimmermark, 2004) revealed that about $70-80 \mathrm{wt} . \%$ of the fraction $<18 \mathrm{~mm}$ (1722 years old waste) in all excavated depths was within the size range $10-1 \mathrm{~mm}$.

Figure 1 depicts the particle size distribution within the fine fractions of additional studies. Most of these studies present similar results to those of Hogland et al., 2004, where the majority of the fine fractions of excavated land- 
TABLE 3: Particle size distribution of excavated waste from previous LFM investigations.

\begin{tabular}{|c|c|c|c|c|c|c|c|c|c|c|c|c|c|}
\hline \multicolumn{2}{|c|}{ 离 } & 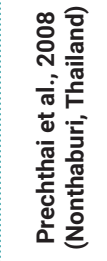 & 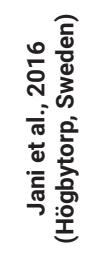 & 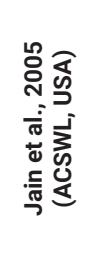 & 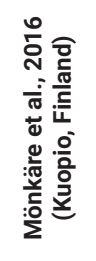 & 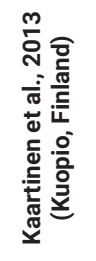 & 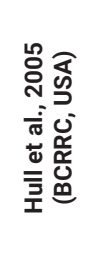 & 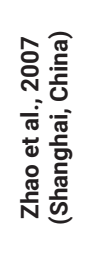 & 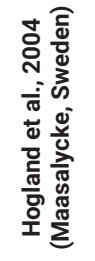 & 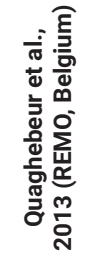 & 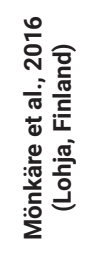 & 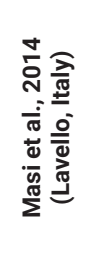 & 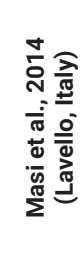 \\
\hline \multicolumn{2}{|c|}{$\begin{array}{l}\text { Type of waste } \\
\text { disposed of }\end{array}$} & MSW & $\begin{array}{c}\mathrm{MSW}+ \\
\mathrm{C} \& \mathrm{D}\end{array}$ & MSW & MSW & MSW & $\begin{array}{c}\text { MSW + } \\
\text { C\&D + } \\
\text { IW }\end{array}$ & MSW & MSW & MSW & $\begin{array}{c}\text { MSW + } \\
\text { C\&D + } \\
\text { soil }\end{array}$ & MSW & MSW \\
\hline \multicolumn{2}{|c|}{ Age of waste [a] } & $3-5$ & 5 & $3-8$ & $1-10$ & $5-10$ & $1-11$ & $8-10$ & $17-22$ & $14-29$ & $24-40$ & $30-60$ & $30-60$ \\
\hline \multirow{19}{*}{ 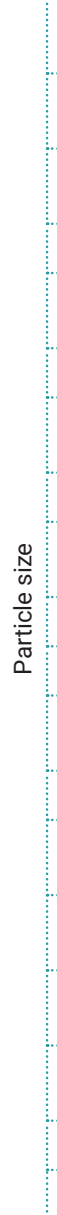 } & $>100 \mathrm{~mm}$ & - & - & - & - & $\begin{array}{l}31.0- \\
34.0 \%\end{array}$ & - & - & - & - & - & - & - \\
\hline & $>50 \mathrm{~mm}$ & $69.0 \%$ & - & - & - & - & - & - & $\begin{array}{l}48.2- \\
59.2 \%\end{array}$ & - & - & - & - \\
\hline & $>40 \mathrm{~mm}$ & - & $24.0 \%$ & - & - & - & - & $\begin{array}{l}25.5- \\
70.6 \%\end{array}$ & - & - & - & - & - \\
\hline & $>6.3 \mathrm{~mm}$ & - & - & $40.9 \%$ & - & - & - & - & - & - & - & - & - \\
\hline & $40-100 \mathrm{~mm}$ & - & - & - & - & $\begin{array}{l}16.0- \\
17.0 \%\end{array}$ & - & - & - & - & - & - & - \\
\hline & $25-50 \mathrm{~mm}$ & $13.0 \%$ & - & - & - & - & - & - & - & - & - & - & - \\
\hline & $18-50 \mathrm{~mm}$ & - & - & - & - & - & - & - & $\begin{array}{l}21.8- \\
31.4 \%\end{array}$ & - & - & - & - \\
\hline & $20-40 \mathrm{~mm}$ & - & - & - & - & $6.0 \%$ & - & - & - & - & - & - & - \\
\hline & $15-40 \mathrm{~mm}$ & - & - & - & - & - & - & $\begin{array}{l}14.9- \\
32.6 \%\end{array}$ & - & - & - & - & - \\
\hline & $10-40 \mathrm{~mm}$ & - & $38.0 \%$ & - & - & - & - & - & - & - & - & - & - \\
\hline & $0.425-6.3 \mathrm{~mm}$ & - & - & $14.5 \%$ & - & - & - & - & - & - & - & - & - \\
\hline & $<25.4 \mathrm{~mm}$ & - & - & - & - & - & $\begin{array}{l}50.0- \\
52.0 \%\end{array}$ & - & - & - & - & - & - \\
\hline & $<25 \mathrm{~mm}$ & $18.0 \%$ & - & - & - & - & - & - & - & - & - & - & - \\
\hline & $<20 \mathrm{~mm}$ & - & - & - & $\begin{array}{l}38.0- \\
53.9 \%\end{array}$ & $\begin{array}{l}43.0- \\
47.0 \%\end{array}$ & - & - & - & - & $\begin{array}{l}39.8- \\
73.6 \%\end{array}$ & - & - \\
\hline & $<18 \mathrm{~mm}$ & - & - & - & - & - & - & - & $\begin{array}{l}14.8- \\
24.7 \%\end{array}$ & - & - & - & - \\
\hline & $<15 \mathrm{~mm}$ & - & - & - & - & - & - & $\begin{array}{l}12.8- \\
45.3 \%\end{array}$ & - & - & - & - & - \\
\hline & $<10 \mathrm{~mm}$ & - & $38.0 \%$ & - & - & - & - & - & - & $\begin{array}{l}44.0 \pm \\
12.0 \%\end{array}$ & - & $70.4 \%$ & - \\
\hline & $<4 \mathrm{~mm}$ & - & - & - & - & - & - & - & - & - & - & - & $63.6 \%$ \\
\hline & $<0.425 \mathrm{~mm}$ & - & - & $44.6 \%$ & - & - & - & - & - & - & - & - & - \\
\hline & Notes: & $\begin{array}{l}\text { Informat } \\
\text { Figures } \\
M S W-M \\
C \& D-C o \\
\text { IW - Indu }\end{array}$ & $\begin{array}{l}\text { norganize } \\
\text { ve weight } \\
\text { nicipal sol } \\
\text { truction a } \\
\text { rial waste }\end{array}$ & $\begin{array}{l}\text { accordin } \\
\text { asis } \\
\text { waste } \\
\text { d demolit }\end{array}$ & $\begin{array}{l}\text { o age of } \\
\text { waste }\end{array}$ & & & & & & & & \\
\hline
\end{tabular}

fill MSW / MSW + C\&D / MSW + C\&D + IW / MSW + C\&D + soil with various waste ages were composed of a particle size over $1 \mathrm{~mm}$.

On the other hand, according to Jani et al., 2016 the fraction $<10 \mathrm{~mm}$ represented $38 \mathrm{wt}$.\% of the total excavated material (5 years old MSW + C\&D material) and were composed mainly of soil-like material and minerals; from which $98 \mathrm{wt}$ \% were smaller than $4 \mathrm{~mm}$ and $80 \mathrm{wt}$ \% were smaller than $2 \mathrm{~mm}$.

Previous LFM studies have similar results. For instance, Mönkäre et al., 2016 reported that about 78-81 wt.\% of the fraction $<20 \mathrm{~mm}$ was smaller than $11.2 \mathrm{~mm}$ and about 51 -
52 wt.\% of it was smaller than $5.6 \mathrm{~mm}$ in a landfill containing 1-10 years old waste (MSW), whilst a site with 24-40 years old waste (MSW + C\&D + soil) presented ratios of 88-93 wt.\% and 66-74 wt.\% (except one sample having 40 wt.\% under $5.6 \mathrm{~mm}$ ), respectively, for the same fraction.

Miller, Earle, \& Townsend, 1996 reported that most (around $99 \%$ ) of the landfill cover soil passed through a sieve of $0.425 \mathrm{~mm}$, while retaining a majority of the biodegradable material. The fine fraction $<0.425 \mathrm{~mm}$ was composed mainly of sand, which had the lowest organic matter content of all three fractions. Moreover, together the fractions $<0.425 \mathrm{~mm}$ and $0.425-6.3 \mathrm{~mm}$ constituted about 60 


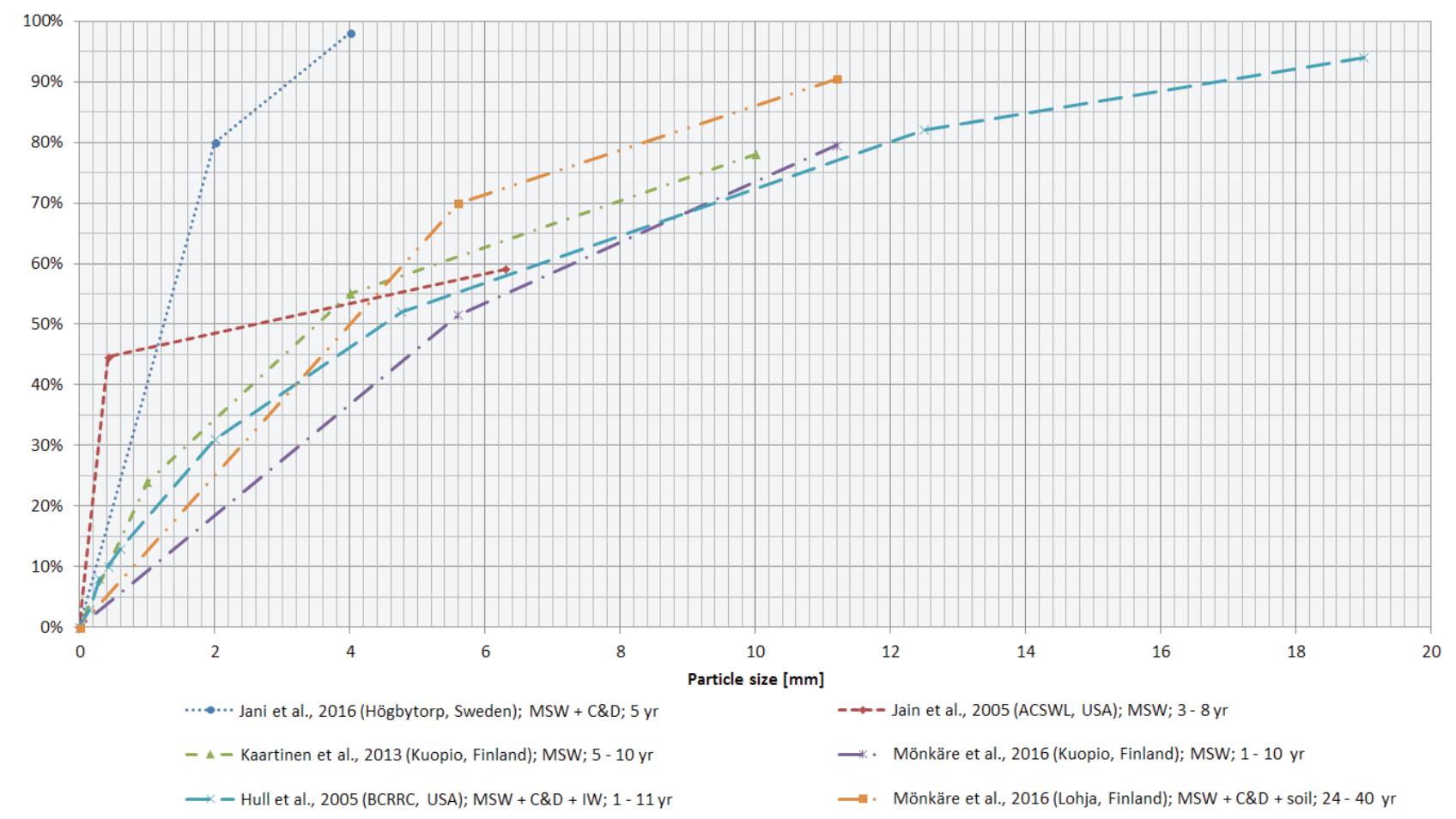

FIGURE 1: Particle size distribution within excavated fine fractions from previous LFM investigations.

wt.\% of the excavated landfill MSW (3-8 years old) by Jain et al., 2005; where 44.6 wt.\% corresponded to the fraction $<0.425 \mathrm{~mm}$ and $14.5 \mathrm{wt}$.\% to the fraction $0.425-6.3 \mathrm{~mm}$.

Excavated landfill MSW (10 years old waste), which consisted of around $54 \mathrm{wt} . \%$ material $<40 \mathrm{~mm}$ and about $46 \mathrm{wt} . \%$ material $>40 \mathrm{~mm}$, exhibited a slight increase in the amount of the material $<40 \mathrm{~mm}$ with depth (Burlakovs, Kaczala et al., 2016; Bhatnagar et al., 2017). The results obtained by Kaartinen et al., 2013 indicated transport of the fraction < $20 \mathrm{~mm}$ (5-10 years old excavated MSW) towards the bottom layer of the landfill as well. The age of the disposed waste can affect the particle size distribution in a landfill (Hull et al., 2005); several fractions of the older waste (7-11 years old MSW + C\&D + IW) presented greater amounts of material $<25.4 \mathrm{~mm}$. Thus, it can be inferred that the amount of fine fractions might increase over time due to the reduction of the particle size of certain waste materials, mainly organic materials, driven by biodegradation and weathering effects. However, it is relevant to point out that a larger amount of fine particles can be found in deeper layers of the landfill due to vertical transport (i.e. downward migration due to gravitational force) rather than biodegradation and weathering effects, which could mislead to the consideration of higher values for the decrease in particle size due to degradation of waste over time.

Other interesting findings include that, for example, a visual inspection by Kaartinen et al., 2013 indicated that the fraction $<4 \mathrm{~mm}$ was predominantly composed of soil. Spooren et al., 2012 reported an average of $43 \mathrm{wt}$ \% for the fraction < $10 \mathrm{~mm}$ from excavated landfill MSW (14-29 years old material). Hull et al., 2005 suggested that in order to remove all visual contaminants a $2 \mathrm{~mm}$ screen is to be employed, since non-soil materials such as plastic, paper flakes and broken glass generally did not pass through; in this manner the mass of the fraction $<25.4 \mathrm{~mm}$ could be reduced by about $70 \%$ as well.

According to Spooren et al., 2012, common industrial waste separation techniques are unable to sort materials with a particle size below a certain threshold, which often lies within the range of 2-10 $\mathrm{mm}$.

From the gathered information above it can be extracted that: the amount of the fine fractions in landfilled MSW seems to increase over time, whereas their particle size seems to decrease; in a landfill a larger amount of fines could be expected with depth; most of the material composing the fine fractions from excavated landfill MSW is likely to have a particle size larger than $1 \mathrm{~mm}$; most of non-soil materials such as plastics, paper, textiles, stones and broken glass and ceramics could be removed through sieving (probably around $2 \mathrm{~mm}$ ); the under-sieve material could be expected to be mainly soil-like material (including inert materials) and landfill cover soil and fine inert materials could be recovered via further finer sieving (probably around $0.5 \mathrm{~mm}$ ).

Therefore, it is relevant to emphasize that in LFM and ELFM future investigations the particle size will be a key parameter for the separation of the fine fractions into exploitable resources and the minimization of the material to, if the case, be sent back for re-landfilling. For this, the fine fractions may be classified into certain particle size ranges, selected according to the results of the material characterization and particle size distribution during the exploration phase of a LFM project, to determine the cutoff diameter size for the fine fractions and enable more efficient material recovery, for different purposes (e.g. recycling and alternative fuel), and recuperation of soil-like 
and inert materials in the corresponding processing techniques (e.g. density, magnetic and eddy-current separators, among others). This can result very useful to implement a material processing approach especially designed for the particular characteristics of each particle size range, as well as to concentrate some of the moisture and undesired substances (e.g. heavy metals) into a few of the finest particle size ranges.

\subsection{Moisture and organic content}

The moisture content of the excavated waste is an important characteristic that determines the environmental conditions in the landfill and plays an important role when considering the material processing (Hull et al., 2005). In a landfill it depends on many interrelated factors, such as waste composition (e.g. percentage of organic matter, plastics, inert, etc.), waste type (e.g. MSW, C\&D, Industrial waste), waste properties, local climate and weather conditions, landfill operation procedures, gas and leachate collection systems, water generation and consumption due to microbiological activity, between others (Qian, Koerner, \& Gray, 2002). Moisture is predominantly present in the fine fractions, as small pores hold water stronger than large pores (capillary action). This is why moisture is a key parameter regarding the treatment of the fine fractions.

Moreover, moisture is one of the most relevant factors influencing the biodegradation of organic matter, playing a vital role in all microorganism's metabolism, and, hence, it is highly interrelated with the organic content in a landfill (Bäumler \& Kögel-Knabner, 2008). The water content is also related to the organic content because organic matter can store a manifold of its own weight of water; this is also valid for certain types of clay minerals. Furthermore, the microbial activity and organic matter play a very important role in the absorption and mobilization of metals (Bozkurt, Moreno, \& Neretnieks, 1999; Bradl, 2005).

The water content of the excavated waste can vary significantly and needs to be taken into account when assessing the valorization and treatment options for ELFM (Quaghebeur et al., 2013). It is to be noted that the sampling procedure and the approach with which the water content is determined might have relevant effects on the determined value and, hence, the real water content might differ from the calculated value. For example, the calculated water content can result in a lower value due to water losses during sampling and sieving activities.

Previous experiences include that moisture contained in excavated waste did not impede its processability, but it might have affected the processing efficiency (Kaartinen et al., 2013). Thus, some studies have recurred to the drying of the fines fraction for better results (Hull et al., 2005; Jain et al., 2005; Kaartinen et al., 2013; Kurian et al., 2003; Prechthai et al., 2008; Quaghebeur et al., 2013). Drying of the fine fractions could: (i) reduce the amount of surface defilements; increasing the quality of the recyclable materials and raising the efficiency of sorting processes, especially for the sensor-based sorting technologies, such as near infrared (NIR) and color recognition (VIS), (ii) enable a more efficient and precise particle size classification in the screening and sieving processes, (iii) decrease the total amount of material to be processed and, perhaps, transported and (iv) raise the calorific value.

An additional study by Jain et al., 2005, investigated differences regarding physical appearance, such as presenting darker color, smaller particle size and higher degree of degradation for landfill-mined material which has been previously exposed to leachate recirculation; while no significant difference was observed in the mean moisture content when compared with landfill-mined material without leachate recirculation.

Like the moisture also the organic matter is enriched in the fine fraction, as degradation processes of biowaste decrease its grain size over time in a landfill. Table 4 shows the results obtained on moisture and organic contents from various LFM studies. Into this respect it can be observed that the moisture content varies between 16 and 54 wt.\% and the organic matter content between 9 and 21 wt.\% (dry matter) for landfills with comparable ages (up to 10 years) and type (MSW) of disposed material, as well as similar particle sizes (<20 mm); while for older excavated material ( 17 to 40 years old) the moisture and organic content seem to decrease slightly to ranges of $18-40 \mathrm{wt} . \%$ and 5-14 wt.\% (dry matter), respectively.

The decrease of organic matter content with the increase of the age of the waste was also observed by Mönkäre et al., 2016 and Hull et al., 2005. This showed congruency with the results obtained by Francois et al., 2006 as well, indicating that younger material is less degraded than older material. Thirty year old material presented volatile solid contents (VS) characteristics for stabilized material (Kelly, 2002). Ayuso, Hernández, García, \& Pascual, 1996 reported that the organic matter content of 30 year old material were close to the characteristics of soil. In this respect, a model (Tabasaran \& Rettenberger, 1987) can be used to estimate the organic decay in landfill through the prognosis of landfill gas generation.

It has been observed that organic matter influences the capacity of waste to hold water, known as field capacity (Sormunen et al., 2013; Zornberg, Jernigan, Sanglerat, \& Cooley, 1999). The higher the content of organic matter, the higher is the water content to be expected (Hull et al., 2005). The biodegradable organic matter content in the waste reported by Zhao et al., 2007 was significantly higher than in the cover soil used at the landfill.

The contents of total and volatile solids determined by Mönkäre et al., 2016 showed no trends regarding site or depth and her results indicate that organic matter can remain for a long time in a landfill, which is explained by the formation of stable humic substances during the biodegradation of organic matter. Volatile solids, despite not a measure of available organic matter, might be a simple and inexpensive way to assess the potential degradability of the excavated waste from a landfill (Hull et al., 2005).

The composition of the cover layer employed at a site seems to play a relevant role regarding the waste degradation rate; meaning that the degradation process could be significantly faster with the use of a high to medium permeability material (e.g. compost) than with a low permeability one (e.g. clay) (Francois et al., 2006). This can be explained by the fact that the use of a permeable material as cover 
TABLE 4: Organic content, total solids and water content of excavated fine fractions from previous LFM investigations.

\begin{tabular}{|c|c|c|c|c|c|c|c|c|c|c|c|}
\hline 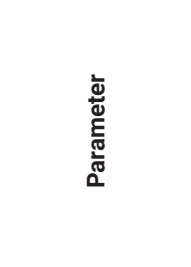 & 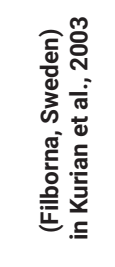 & 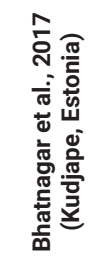 & 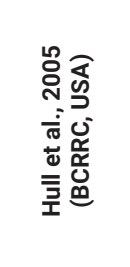 & 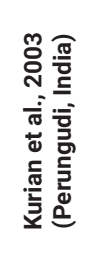 & 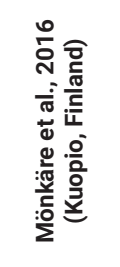 & 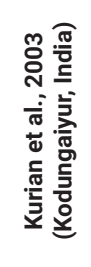 & 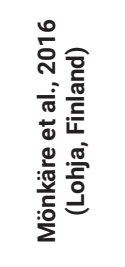 & 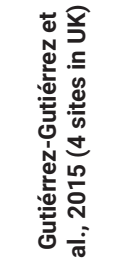 & 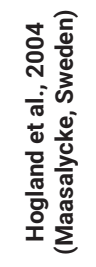 & 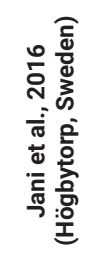 & 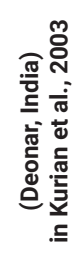 \\
\hline $\begin{array}{l}\text { Type of waste } \\
\text { disposed of }\end{array}$ & MSW & MSW & $\begin{array}{c}M S W+ \\
C \& D+I W\end{array}$ & MSW & MSW & MSW & $\begin{array}{c}\text { MSW + } \\
\text { C\&D + } \\
\text { soil }\end{array}$ & $\begin{array}{c}\text { MSW and } \\
\text { MSW + } \\
\text { C\&I }\end{array}$ & MSW & $\begin{array}{c}\text { MSW + } \\
\text { C\&D }\end{array}$ & MSW \\
\hline $\begin{array}{c}\text { Age of waste } \\
{[a]}\end{array}$ & - & 10 & $1-11$ & $0-10$ & $1-10$ & 10 & $24-40$ & - & $17-22$ & 5 & - \\
\hline $\begin{array}{c}\text { Particle size } \\
{[\mathrm{mm}]}\end{array}$ & $<40$ & $<40$ & $<25.4$ & $<20$ & $<20$ & $<20$ & $<20$ & $<19$ & $<18$ & $<10$ & $<8$ \\
\hline Organic content & - & - & - & $\begin{array}{c}8.9- \\
15.8 \%\end{array}$ & $\begin{array}{c}8.8 \pm 0.4 \\
-16.9 \pm \\
0.7 \%\end{array}$ & $\begin{array}{c}8.9- \\
20.7 \%\end{array}$ & $\begin{array}{c}4.9 \pm 0.4 \\
-14.3 \pm \\
0.8 \%\end{array}$ & $\begin{array}{c}25.0 \pm \\
10.0- \\
41.0 \pm \\
9.0 \%\end{array}$ & - & $16.6 \%$ & $14.5 \%$ \\
\hline Total solids & - & - & - & - & $\begin{array}{c}46.2 \pm \\
1.7-63.7 \\
\pm 1.7 \%\end{array}$ & - & $\begin{array}{c}59.6 \pm \\
1.6-81.6 \\
\pm 1.0 \%\end{array}$ & - & - & - & - \\
\hline Water content & $\begin{array}{l}30.0- \\
38.0 \%\end{array}$ & $\leq 40.0 \%$ & $\begin{array}{l}16.0- \\
43.0 \%\end{array}$ & $\begin{array}{l}21.4- \\
52.0 \%\end{array}$ & - & $\begin{array}{l}15.5- \\
46.0 \%\end{array}$ & - & $\begin{array}{c}58.0 \pm \\
70 .-79.0 \\
\pm 9.0 \%\end{array}$ & $\begin{array}{l}22.3- \\
28.8 \%\end{array}$ & $23.5 \%$ & $14.0 \%$ \\
\hline Notes: & \multicolumn{11}{|c|}{$\begin{array}{l}\text { Information organized according to particle size } \\
\text { Figures have weight basis } \\
\text { MSW - Municipal solid waste } \\
\text { C\&D - Construction and demolition waste } \\
\text { IW - Industrial waste } \\
\text { PPC - Paper, paperboard and cardboard }\end{array}$} \\
\hline
\end{tabular}

layer in a landfill could favor the aerobic biological degradation of certain organic components, which degrade at a faster rate in aerobic than in anaerobic conditions. This could mean that waste from landfill sites where low permeability cover materials were used might present higher organic content, which could eventually be found in the fine fractions. Nonetheless, the use of compost as cover material might raise the organic content of the fine fractions as well.

Studies in Europe on fresh organic MSW have revealed that the average total organic carbon remains relatively stable, around $43-44 \mathrm{wt} . \%$, despite the heterogeneity of the organic matter content (Baky \& Eriksson, 2003; Iglesias Jimenez \& Perez Garcia, 1992), suggesting that the variation of this parameter in the fine fractions from LFM depends strongly on the treatment of the MSW before disposal and the conditions at the landfill site.

From this information it can be concluded that significant amounts of organic matter and moisture are likely to be present in LFM material and, eventually, to be found in the fine fractions. These interrelated parameters are of critical relevance, since processing routes and possible end-uses for these fractions will depend on their quantities. Depending on the amount of moisture it can be determined if a dry or wet further processing of the material is to be employed and the efficiency of the chosen method will depend considerably on the moisture content. The organic content can be used to determine if material or energy recovery routes should be pursued or, otherwise, if the material is suitable to be re-landfilled according to the legislation in force.

Fine fractions might be used in the future to predict the moisture content in samples containing all fractions, as results on moisture between samples of fines and samples containing all fractions have shown good correlation and representative samples of the fines are easier to take than those containing all fractions (Hull et al., 2005).

\subsection{Physico-chemical properties}

Table 5 displays data on some physico-chemical properties of the fine fractions obtained in the reviewed investigations. This information shows that most of the compared parameters presented roughly similar ranges within different sites, taking into account the differences among them (mainly in particle size and age of waste).

Characteristics such as calorific value, amount of organic carbon, total carbon, ash content, hydrogen and nitrogen contents are needed to assess the efficiency for WtE applications (Quaghebeur et al., 2013).

Most physical, chemical and microbial processes, such as dissolution of waste materials and metabolites and emissions of volatile substances, as well as the pressure conditions, in a landfill are affected by temperature (Hull et al., 2005). The temperature of landfilled waste has been seen to increase with a rate of approximately $1{ }^{\circ} \mathrm{C}$ per $\mathrm{m}$ of depth (Attal, Akunna, Camacho, Salmon, \& Paris, 1992; Gurijala \& Suflita, 1993; Hull et al., 2005; Zornberg et al., 1999). Temperature also plays a decisive role regarding microbiological activity and biochemical reactions inside the landfill, which are linked in parallel to the moisture, organic 
matter content and $\mathrm{pH}$, among others.

The calorific value of a waste fraction is mainly driven by the amount of carbon (usually measured as total carbon or total organic carbon) and the ash and moisture contents.

Chemically, fine fractions of landfill mining consist mainly of $\mathrm{SiO}_{2}, \mathrm{CaO}, \mathrm{Al}_{2} \mathrm{O}_{3}$ and $\mathrm{FeO}$ (Spooren et al., 2012). However, the recovery of these compounds is limited by the presence of environmentally problematic elements, especially heavy metals. Nevertheless, the environmental impact of a material does not depend on its total content of hazardous substances, but on their mobility. Some parameters of significance in control of metal mobility such as $\mathrm{pH}$, sulfide, sulfate and chloride contents in a landfill have been studied by Gould, Cross, \& Pohland, 1990; the latter reported that a broad range of attenuating mechanisms limiting the mobility of toxic metals in the leachate from columns simulating landfill material with shredded MSW occurred, suggesting that MSW has a capacity for minimizing the mobility of heavy metals.

The values for $\mathrm{pH}$ and phosphorous of the fines fraction complied with the limits for compost standards, while the contents of $\mathrm{N}$ and $\mathrm{K}$ did not (Prechthai et al., 2008). The variation of $\mathrm{pH}$ towards the bottom of a dumpsite show the varying decomposition rate of organic waste (Das, Smith, Gattie, \& Hale Boothe, 2002; Townsend, Miller, Lee, \& Earle, 1996). It is known that the $\mathrm{pH}$ of waste varies over time in a landfill depending on the phase the waste is going through, i.e. aerobic phase, anaerobic phase (acidic and methanogenic phases) and humic phase; where the waste presents a $\mathrm{pH}$ close to 7 units at the beginning, decreases to about 4-6 units in the acidic phase, raises back to around 7-8 units during the methanogenic phase and remains slightly basic, approximately 8 units, for the humic phase (Bozkurt et al., 1999). The humic phase is reached when all the readily degradable organic matter has been degraded and remains in the waste in a very stable substance state (Bozkurt et al., 1999). This suggests that the $\mathrm{pH}$ of the waste in a landfill can be expected to decrease with depth in some cases; depending on the characteristics of the site, operational procedures and type of waste contained. Nonetheless, it is to be considered that due to the strong heterogeneity in a landfill, different parts of the landfill might develop at different rates (Bozkurt et al., 1999) and, thus, a decreasing tendency of the $\mathrm{pH}$ with depth might not be always the case. $\mathrm{A} \mathrm{pH}$ variation within the range of 4-9 units was observed in the reviewed investigations displayed in Table 5. Low pH and high TOC values are indicators of incomplete biodegradation of the material (Kurian et al., 2003).

The nutrient contents were low for two observed landfills; especially total phosphorus was below detection limit of $10 \mathrm{mg} / \mathrm{kg}$ (dry matter) in most sampling points (Mönkäre et al., 2016). Results obtained by Hogland et al., 2004 for total phosphorus showed similar concentrations. Values for fresh biowaste from household waste in Denmark

TABLE 5: Physico-chemical properties of excavated fine fractions from previous LFM investigations.

\begin{tabular}{|c|c|c|c|c|c|c|c|c|c|c|c|c|c|c|}
\hline 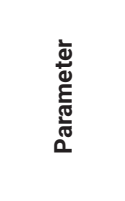 & 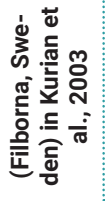 & 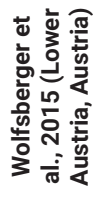 & 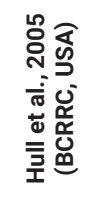 & 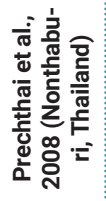 & 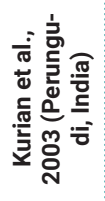 & 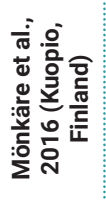 & 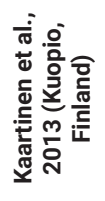 & 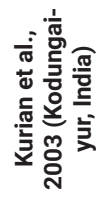 & 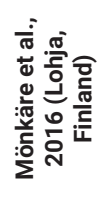 & 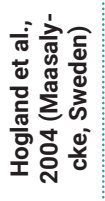 & 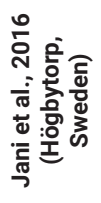 & 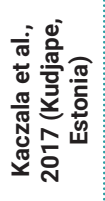 & 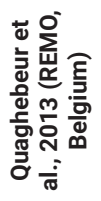 & 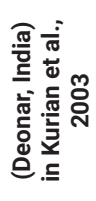 \\
\hline $\begin{array}{c}\text { Type of } \\
\text { waste dis- } \\
\text { posed of }\end{array}$ & MSW & MSW & $\begin{array}{c}\mathrm{MSW}+ \\
\mathrm{C \& D}+ \\
\mathrm{IW}\end{array}$ & MSW & MSW & MSW & MSW & MSW & $\begin{array}{c}\text { MSW + } \\
\text { C\&D + } \\
\text { soil }\end{array}$ & MSW & $\begin{array}{c}\text { MSW + } \\
\text { C\&D }\end{array}$ & MSW & MSW & MSW \\
\hline $\begin{array}{c}\text { Age of } \\
\text { waste [a] }\end{array}$ & - & $13-20$ & $1-11$ & $3-5$ & $0-10$ & $1-10$ & $5-10$ & 10 & $24-40$ & $17-22$ & 5 & $5-6$ & $14-29$ & - \\
\hline $\begin{array}{l}\text { Particle } \\
\text { size }[\mathrm{mm}]\end{array}$ & $<40$ & $<40$ & $<25.4$ & $<25$ & $<20$ & $<20$ & $<20$ & $<20$ & $<20$ & $<18$ & $<10$ & $<10$ & $<10$ & $<8$ \\
\hline $\begin{array}{c}\text { Ash } \\
\text { content }\end{array}$ & $78.9 \%$ & - & - & $68.6 \%$ & $\begin{array}{l}84.2- \\
91.1 \%\end{array}$ & - & - & $\begin{array}{l}79.3- \\
91.1 \%\end{array}$ & - & $\begin{array}{l}87.3- \\
90.2 \%\end{array}$ & - & - & $\begin{array}{c}64.4- \\
85.0 \%\end{array}$ & - \\
\hline $\begin{array}{c}\text { Bulk } \\
\text { density } \\
{\left[\mathrm{kg} / \mathrm{m}^{3}\right]}\end{array}$ & $\begin{array}{c}400- \\
500\end{array}$ & - & $\begin{array}{l}370- \\
1,206\end{array}$ & - & $\begin{array}{l}745- \\
1,147\end{array}$ & - & - & $\begin{array}{l}853- \\
1,254\end{array}$ & - & - & 690 & - & - & - \\
\hline $\begin{array}{l}\text { Calorific } \\
\text { value } \\
{[\mathrm{MJ} / \mathrm{kg}]}\end{array}$ & - & $\begin{array}{l}4.4- \\
9.0\end{array}$ & - & - & - & - & - & - & - & $\begin{array}{c}0.4- \\
0.9\end{array}$ & 1.7 & - & $\begin{array}{l}2.2- \\
4.8\end{array}$ & - \\
\hline $\mathrm{pH}$ & $\begin{array}{l}4.0- \\
5.0\end{array}$ & - & - & $\begin{array}{c}7.7 \pm \\
0.3\end{array}$ & $\begin{array}{l}7.6- \\
8.6\end{array}$ & $\begin{array}{l}6.8- \\
7.6\end{array}$ & $\begin{array}{c}8.1 \pm \\
0.1- \\
8.3 \pm \\
0.1\end{array}$ & $\begin{array}{l}6.9- \\
8.1\end{array}$ & $\begin{array}{l}7.2- \\
7.9\end{array}$ & $\begin{array}{l}7.0- \\
7.3\end{array}$ & 7.7 & $\begin{array}{l}7.1- \\
8.3\end{array}$ & - & 7.2 \\
\hline $\begin{array}{l}\text { Total } \\
\text { organic } \\
\text { carbon }\end{array}$ & $13.0 \%$ & $\begin{array}{l}10.0- \\
20.0 \%\end{array}$ & - & - & $\begin{array}{l}5.2- \\
7.9 \%\end{array}$ & $\begin{array}{l}4.7- \\
5.6 \%\end{array}$ & $\begin{array}{c}4.7 \pm \\
0.8- \\
5.8 \pm \\
1.6 \%\end{array}$ & $\begin{array}{c}4.5- \\
10.4 \%\end{array}$ & - & - & $5.6 \%$ & $\begin{array}{l}0.2- \\
0.4 \%\end{array}$ & $\begin{array}{c}7.6- \\
12.4 \%\end{array}$ & $5.8 \%$ \\
\hline Notes: & \multicolumn{14}{|c|}{$\begin{array}{l}\text { Information organized according to particle size } \\
\text { Percentage figures have weight basis } \\
\text { MSW - Municipal solid waste } \\
\text { C\&D - Construction and demolition waste } \\
\text { IW - Industrial waste }\end{array}$} \\
\hline
\end{tabular}


for nitrogen content reported by Riber, Petersen, \& Christensen, 2009 were significantly higher than the ones from landfilled material reported by Hogland et al., 2004 and Mönkäre et al., 2016. This reflects the consumption and migration of the nutrient content in the fine fractions after disposal. Total nitrogen and phosphorus measurements by Zhao et al., 2007 in fine fractions indicated that nitrogen levels decrease over time, whereas phosphorus levels remain steady; the measured contents of these elements in the fine fractions were higher than in the cover layer.

The chemical oxygen demand and heavy metals, chlorides and fluorides contents in leachate of the fine fractions can be useful to identify the ability to reuse these fractions as a construction material outside the landfill, landfill cover material or for landfilling as inert material (Jani et al., 2016). The sulfur, chlorine, fluorine and bromine content of waste is needed to assess the emission levels during thermal conversion (Quaghebeur et al., 2013).

According to Kaartinen et al., 2013, the fine fractions exhibited generally non-hazardous properties in leaching tests performed to assess landfill acceptability; nevertheless, leaching of dissolved organic carbon from fine fractions of young disposed MSW may be challenging for landfill disposal in the EU. Therefore, $\mathrm{pH}$-dependent leaching tests (e.g. European standard EN 14429) might result essential to identify the recycling possibilities of waste materials like the fine fractions.

Jani et al., 2016 reported that the calorific value, methane gas potential and total organic carbon decreased with the time waste has been disposed of, since lower values were obtained for the waste in older layers of the landfill, where the organic materials showed a larger decomposition. The determination of the methane potential could be used to identify the suitability of the fine fractions for energy recovery or the need for stabilization to prevent emissions (Mönkäre et al., 2016).

As shown in Table 5, mostly low heating values (between 0.4-4.8 MJ/kg) were reported for the fine fractions in previous LFM studies (Hogland et al., 2004; Jani et al., 2016; Quaghebeur et al., 2013). Nonetheless, Wolfsberger et al., 2015 obtained higher values (around 4.4-9 MJ/kg). As already stated, moisture, carbon and ash contents are highly interrelated with respect to the calorific value and, despite the lack of information regarding these parameters for some of the compared studies, it could be observed that the highest calorific value range (4.4-9 MJ/kg) corresponds to the highest total organic content range (10-20 wt.\%), whereas the lowest calorific value range (0.4-0.9 $\mathrm{MJ} / \mathrm{kg}$ ) corresponds to the highest ash content range (87.3-90.2 wt.\%).

There was not enough comparable information in the studies presented in Table 5 to identify a correlation between particle size and age of waste regarding the calorific value. Nevertheless, additional previous investigations reported that the calorific value and total organic carbon concentration decreased with increasing storage time of the waste in the landfill; what is most likely the result of decomposition of carbon-rich material into landfill gas over time (Quaghebeur et al., 2013). The analyses from Masi et al., 2014 show that the fraction $<4 \mathrm{~mm}$ has a percentage of the total organic carbon more than six times higher than a conventional agrarian soil.

The bulk density showed a variation from 370 to 1,254 $\mathrm{kg} / \mathrm{m}^{3}$ in Table 5; where the lowest density range (400-500 $\left.\mathrm{kg} / \mathrm{m}^{3}\right)$ corresponds to the coarsest particle size $(<40 \mathrm{~mm})$ from the compared studies. The highest bulk density ranges (853-1,254 and 745-1,147 kg/m³) corresponded to a particle size of $<20 \mathrm{~mm}$, which was not the finest particle size from the compared studies but presented the highest ash content ranges (79.3-91.1 and 84.2-91.1 wt.\%).

The cellulose content, cellulose-to-lignin or cellulose-to-VS ratios have been used in MSW decomposition studies as an indicator of degradation grade of the waste in landfills (Bookter \& Ham, 1982; Ham, Norman, \& Fritschel, 1993; Jones, Rees, \& Grainger, 1983; Mehta et al., 2002; Wang, Byrd, \& Barlaz, 1994). A cellulose-to-lignin ratio of < 0.2 (30 year old waste) indicates relatively well stabilized waste compared to less degraded waste with a ratio of 0.9-1.2 and fresh waste with a ratio of 4 (Bookter \& Ham, 1982). These ratios could be used to determine the degree of degradation of the fine fractions and, thereby, evaluate their material or energy recovery potential.

Phytotoxicity was tested by Masi et al., 2014, which reported that the acute tests did not demonstrate particularly adverse effects on the growth of test species for two of three species. According to the results obtained by Prechthai et al., 2008 the phytotoxicity of waste to inhibit the germination of rice seed was relatively low and signified the completed degradation of organic matter in the fines fraction; suggesting the safe and suitable usage of the material as compost for non-edible crops. For this, materials like stone, glass, metal and plastics, which can be a problem in the soil, are to be removed (Masi et al., 2014; Prechthai et al., 2008). However, it has to be considered, that limit values with respect to the total and leachable contents of environmentally problematic substances can be far below the concentrations which yield a visible effect in ecotoxicity tests. Consequently, the lacking phytotoxicity of a material does not allow its recycling per se.

\subsection{Metals content}

Table 2 shows that the contents of total metals in LFM fine fractions were relatively low regarding metal recovery potential; except for a site in the USA, where the disposal of industrial waste (IW) and construction \& demolition waste (C\&D) together with MSW was registered, and a site in Sweden, where the upper limit of the fine fraction was set at a coarser particle size $(<40 \mathrm{~mm})$. The latter presented a considerably higher amount of metals than a study in Austria that contained the same type of waste (only MSW) and used the same particle size as upper limit for the fines fraction (Wolfsberger et al., 2015). Spooren et al., 2012 found an amount of $3 \pm 2$ wt.\% of ferromagnetic material (such as ferromagnetic metals and metal oxides) in the fraction < $10 \mathrm{~mm}$ of excavated landfill MSW with respect to the same fraction.

Furthermore, amounts of around $99.9 \%$ metals and around $90 \%$ non-metals, of their whole amount within the fines, have been reported as still found in the fines at the beginning of the humic phase by Belevi \& Baccini, 1989 and 
Bozkurt et al., 1999, showing low degradation of metals in a landfill.

It is relevant to mention that the removal of metals could be negatively influenced when the reach of the metal sorting equipment is limited to larger particle sizes or the metals present poor quality, as they might be oxidized and in degraded conditions.

Nonetheless, there have been additional studies where the amount of metals has been found in significant concentrations, such as a study on the content of metallic elements in the fraction $<10 \mathrm{~mm}$, at different depths, of the excavated waste from a MSW landfill (Burlakovs, Kaczala et al., 2016), which unveils that interesting concentrations of several metals with respect to material recovery, i.e. Fe (average concentrations above $10,000 \mathrm{mg} / \mathrm{kg}$ ), $\mathrm{Mg}$ and $\mathrm{Zn}$ (average concentrations above $1,000 \mathrm{mg} / \mathrm{kg}$ ), can be found in the fine fractions of landfilled waste, as well as concentrations above $100 \mathrm{mg} / \mathrm{kg}$ of metals like $\mathrm{Mn}, \mathrm{Ba}, \mathrm{Cu}, \mathrm{Pb}$ and $\mathrm{Sr}$. Also, results on the fraction $<40 \mathrm{~mm}$ show that the metal content (mainly $\mathrm{Fe}, \mathrm{Al}$ and $\mathrm{Cu}$ ) was about $0.6 \mathrm{wt}$.\% of the same fraction (Burlakovs, Kriipsalu et al., 2016). Significant concentration ranges of $\mathrm{Al}(12,079-17,274 \mathrm{mg} / \mathrm{kg})$ and $\mathrm{Cu}$ $(1,027-2,595 \mathrm{mg} / \mathrm{kg})$, in waste mined from landfills were reported by Gutiérrez-Gutiérrez, Coulon, Jiang, \& Wagland, 2015. Bhatnagar et al., 2017 identified $1 \mathrm{wt} . \%$, of the total amount of the fraction $<40 \mathrm{~mm}$, of $\mathrm{Fe}, \mathrm{Cu}$ and $\mathrm{Al}$ in the same fraction.

Additionally, the amount of magnetic metals recovered from a full-scale process by Kaartinen et al., 2013 was around $1 \mathrm{wt}$.\% from the total processed waste; moreover, this amount was smaller than the amount of total metals separated by manual sorting, which was 3-4 wt.\%. Al and Fe recovery from the fine fractions are of interest; as their concentrations in the fines could yield around 2-2.5 wt.\% of $\mathrm{Al}$ and $1.5-2 \mathrm{wt} . \%$ of Fe of the total amount of the same fraction (Kaartinen et al., 2013).

Chemical analyses of fine fractions do not give information about the oxidation state of metals. However, under landfill conditions it is obvious that metals like $\mathrm{Ca}, \mathrm{Mg}, \mathrm{K}$ and $\mathrm{Na}$, but also a significant proportion of $\mathrm{Fe}$ are present in oxidized form as minerals. Among these, $\mathrm{Ca}$ and Fe were the metals with higher concentration ranges, with 70,000$80,000 \mathrm{mg} / \mathrm{kg}$ and $30,000-50,000 \mathrm{mg} / \mathrm{kg}$, respectively, in the fraction < $10 \mathrm{~mm}$; followed by $\mathrm{Mg}, \mathrm{K}, \mathrm{Na}$ and $\mathrm{Zn}$ (concentrations between 500-20,000 mg/kg), Mn, $\mathrm{Cu}$ and $\mathrm{Pb}$ (concentrations around 150-400 mg/kg) and $\mathrm{Cr}, \mathrm{Ni}$, Co and Cd (concentrations below $150 \mathrm{mg} / \mathrm{kg}$ ), according to Bhatnagar et al., 2017. A similar trend in terms of metal concentrations was found between all excavated pits (Bhatnagar et al., 2017). Interesting concentrations of zinc, copper, barium and chromium for metals recuperation were found by Jani et al., 2016 in the fine fractions.

It is relevant to note that the mineralogical bonding of the individual metals has to be considered when assessing the metals recovery potential of a particular site; as the total amount (mixed with minerals and other materials), the metallic amount and the amount found in compounds (e.g. oxides) of these elements play a crucial role in the determination of the recoverable amount and their speciation.

Moreover, fractions $(<10 \mathrm{~mm}$ ) of excavated industrial waste can contain higher magnetic metals concentrations than mined MSW, seeing that a concentration of around 0.5-5.3 wt.\% of ferromagnetic material was obtained from MSW and one of about 25-29 wt.\% from IW by Spooren et al., 2012 and Quaghebeur et al., 2013. This can be corroborated with the results obtained by Hull et al., 2005 presented in Table 2; in which the metals content was higher in a site where MSW, C\&D and IW were landfilled than in the sites where solely MSW was registered. The analysis of previous studies focused on mining industrial waste from landfill is not within the scope of the present review; nonetheless, the recuperation of metals from landfills for industrial waste might result interesting for future review.

According to the preliminary results obtained by Quaghebeur et al., 2013 the removal of the magnetic metals from the fraction $<10 \mathrm{~mm}$ could result in a reduction of more than $50 \mathrm{wt} . \%$ of the total amount of metals in the same fraction.

The previous information suggests that mechanical processing technologies still have optimization potential for higher yields.

Table 6 encompasses data gathered on specific metals, mainly heavy metals, found in the fine fractions in LFM studies carried out in the past. Heavy metals might accumulate in the fine fractions due to their high specific surface area for interaction (Jain et al., 2005; Wolfsberger et al., 2015). This suggests that a significant part of these heavy metals occur as dissolved species in the pore water or as oxidized precipitates at particle surface. Consequently, the recovery of these metals must include reduction to their elementary state, which would be associated with significant effort.

The results obtained by Masi et al., 2014 showed that the composition of very old dumpsites is relatively uniform and that the concentrations of heavy metals in the fraction $<4 \mathrm{~mm}$ were, on average, 30\% lower than in the fraction $4-10 \mathrm{~mm}$. This suggests that besides the part which is dissolved, adsorbed or that occurs as fine-grained precipitates, another portion of heavy metals might occur in its metallic state. Furthermore, the classification of the fine fractions into determined particle size ranges might be a way to identify and select more accurately the necessary mechanical processing for each particle size range; enabling a more efficient and appropriate processing according to the properties and material recovery potential of each particle size range.

The heavy metal concentration in the waste fractions to be revalorized as refuse derived fuel (RDF) is also to be taken into consideration (Rotter, Kost, Winkler, \& Bilitewski, 2004). It is possible that high concentrations of hazardous substances and heavy metals are found in local pockets (Kurian et al., 2003), since elements such as As, Cd, Co, Cr, $\mathrm{Cu}, \mathrm{Ni}, \mathrm{Pb}, \mathrm{Hg}$ and $\mathrm{Zn}$ can be found in household products (Slack, Gronow, \& Voulvoulis, 2005) and, therefore, in landfill leachate (Reinhart, 1993) depending on the solubility of the respective phases.

For instance, the highest concentrations of $\mathrm{Cr}$ and $\mathrm{Pb}$ found by Prechthai et al., 2008 were in the fine fractions; which was in accordance with the findings reported by Hogland et al., 2004. High concentrations of $\mathrm{Cd}$ and $\mathrm{Pb}$ 
TABLE 6: Metals content in excavated fine fractions from previous LFM investigations.

\begin{tabular}{|c|c|c|c|c|c|c|c|c|c|c|c|c|c|c|c|c|}
\hline 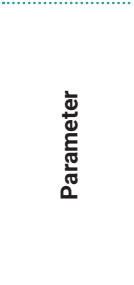 & 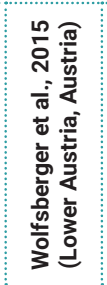 & 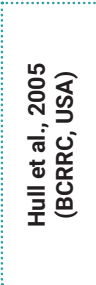 & 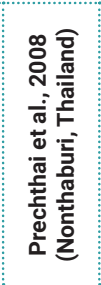 & 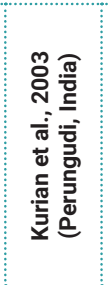 & 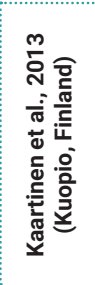 & 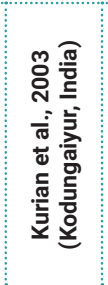 & 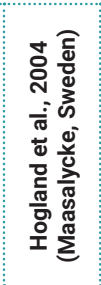 & 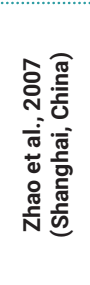 & 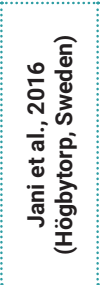 & 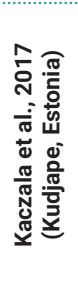 & 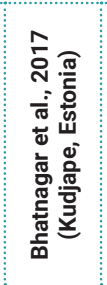 & 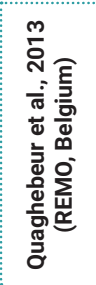 & 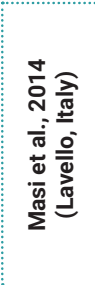 & 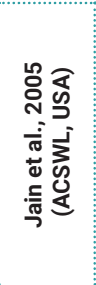 & 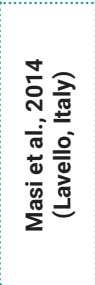 & 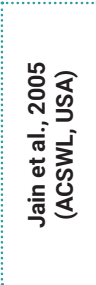 \\
\hline $\begin{array}{c}\text { Type of } \\
\text { waste dis- } \\
\text { posed of }\end{array}$ & MSW & $\begin{array}{c}\text { MSW + } \\
\text { C\&D + } \\
\text { IW }\end{array}$ & MSW & MSW & MSW & MSW & MSW & MSW & $\begin{array}{c}\text { MSW + } \\
\text { C\&D }\end{array}$ & MSW & MSW & MSW & MSW & MSW & MSW & MSW \\
\hline $\begin{array}{c}\text { Age of } \\
\text { waste [a] }\end{array}$ & $13-20$ & $1-11$ & $3-5$ & $0-10$ & $5-10$ & 10 & $17-22$ & $8-10$ & 5 & $5-6$ & 10 & $14-29$ & $30-60$ & $3-8$ & $30-60$ & $3-8$ \\
\hline $\begin{array}{c}\text { Particle } \\
\text { size }[\mathrm{mm}]\end{array}$ & $<40$ & $<25.4$ & $<25$ & $<20$ & $<20$ & $<20$ & $<18$ & $<15$ & $<10$ & $<10$ & $<10$ & $<10$ & $<10$ & $\begin{array}{c}0.425- \\
6.3\end{array}$ & $<4$ & $<0.425$ \\
\hline $\mathrm{Ag}[\mathrm{mg} / \mathrm{kg}]$ & - & - & - & - & - & - & - & - & - & - & - & - & - & $\begin{array}{c}<1.5- \\
24.6\end{array}$ & - & $\begin{array}{l}<1.5- \\
23.8\end{array}$ \\
\hline Al $[\mathrm{g} / \mathrm{kg}]$ & - & - & - & - & $\begin{array}{c}51.0 \pm \\
10.0- \\
57.0 \pm \\
3.1\end{array}$ & - & - & - & - & - & - & - & - & $\begin{array}{c}2.5- \\
169.0\end{array}$ & - & $\begin{array}{l}1.9- \\
76.1\end{array}$ \\
\hline As $[\mathrm{mg} / \mathrm{kg}]$ & $\begin{array}{l}16.0- \\
23.0\end{array}$ & $\begin{array}{l}9.1 \pm \\
8.6\end{array}$ & - & $0.1-1.6$ & - & $0.8-5.6$ & $<0.4$ & - & $\begin{array}{c}5.1 \pm \\
1.7\end{array}$ & - & - & $\begin{array}{c}27.1 \pm \\
15.0\end{array}$ & 73.0 & $\begin{array}{l}1.1- \\
58.6\end{array}$ & 68.0 & $\begin{array}{l}0.2- \\
10.1\end{array}$ \\
\hline $\mathrm{Ba}[\mathrm{mg} / \mathrm{kg}]$ & - & & - & - & $\begin{array}{c}1,100 \\
\pm 100 \\
-900 \pm \\
300\end{array}$ & - & & - & $\begin{array}{c}468.0 \pm \\
143.0\end{array}$ & - & - & & - & $\begin{array}{l}13.8- \\
681.0\end{array}$ & - & $\begin{array}{l}8.2- \\
70.0\end{array}$ \\
\hline $\mathrm{Ca}[\mathrm{mg} / \mathrm{kg}]$ & - & - & - & - & $\begin{array}{c}85,000 \\
\pm \\
39,000 \\
65,000 \\
\pm \\
12,000\end{array}$ & - & & - & - & - & $\begin{array}{l}20,000- \\
60,000\end{array}$ & - & - & - & - & - \\
\hline $\mathrm{Cd}[\mathrm{mg} / \mathrm{kg}]$ & $1.6-4.8$ & $\begin{array}{c}1.2 \pm \\
1.2\end{array}$ & 4.2 & $0.8-1.8$ & $\leq 100$ & $0.9-3.1$ & $0.9-1.2$ & $\begin{array}{l}1.1- \\
10.7\end{array}$ & $\begin{array}{c}2.1 \pm \\
0.6\end{array}$ & - & $0-5$ & $\begin{array}{l}5.9 \pm \\
3.8\end{array}$ & 54.0 & $\begin{array}{c}<0.3- \\
40.0\end{array}$ & 55.0 & $\begin{array}{c}<0.3- \\
13.8\end{array}$ \\
\hline $\mathrm{Co}[\mathrm{mg} / \mathrm{kg}]$ & $\begin{array}{l}6.6- \\
17.0\end{array}$ & - & - & - & - & - & - & - & $\begin{array}{c}23.3 \pm \\
5.8\end{array}$ & - & $5-10$ & - & - & $\begin{array}{c}<0.5- \\
86.7\end{array}$ & - & $\begin{array}{c}<0.5- \\
32.9\end{array}$ \\
\hline $\mathrm{Cr}[\mathrm{mg} / \mathrm{kg}]$ & $\begin{array}{c}130.0- \\
170.0\end{array}$ & $\begin{array}{c}26.0 \pm \\
24.0\end{array}$ & 166.6 & $\begin{array}{c}110.0-0 \\
261.0\end{array}$ & $\begin{array}{c}100 \pm \\
100- \\
200 \pm \\
100\end{array}$ & $\begin{array}{c}191.0- \\
657.0\end{array}$ & $\begin{array}{c}47.0- \\
78.0\end{array}$ & $\begin{array}{l}73.5- \\
252.1\end{array}$ & $\begin{array}{c}254.0 \pm \\
54.0\end{array}$ & - & $10-100$ & $\begin{array}{c}495.7 \pm \\
118.0\end{array}$ & 145.0 & $\begin{array}{c}9.5- \\
531.0\end{array}$ & 117.0 & $\begin{array}{c}2.5- \\
151.0\end{array}$ \\
\hline $\mathrm{Cu}[\mathrm{mg} / \mathrm{kg}]$ & - & - & $2,245.0$ & $\begin{array}{l}75.0- \\
217.0\end{array}$ & $\begin{array}{c}800 \pm \\
1,200 \\
-200 \pm \\
100\end{array}$ & $\begin{array}{c:c}127.0- \\
968.0\end{array}$ & $\begin{array}{c}34.0- \\
36.0\end{array}$ & - & $\begin{array}{r}1,460.0 \\
\pm 684.0\end{array}$ & $\begin{array}{l}45.3- \\
105.2\end{array}$ & $\begin{array}{c}100- \\
300\end{array}$ & $\begin{array}{c}339.3 \pm \\
55.3\end{array}$ & $1,067.0$ & $\begin{array}{r}5.8- \\
5,530\end{array}$ & 538.0 & $\begin{array}{c}0.7- \\
170.0\end{array}$ \\
\hline $\mathrm{Fe}[\mathrm{mg} / \mathrm{kg}]$ & - & - & - & - & $\begin{array}{r}37,000 \\
\pm 1,700 \\
-41,000 \\
\pm 2,100\end{array}$ & - & - & - & $\begin{array}{c}28,724 \\
\pm 8,108\end{array}$ & - & $\begin{array}{l}20,000 \\
60,000\end{array}$ & $\begin{array}{c}27,000 \\
\pm 750\end{array}$ & - & $\begin{array}{l}4,600- \\
61,800\end{array}$ & - & $\begin{array}{c}800- \\
28,200\end{array}$ \\
\hline $\mathrm{Hg}[\mathrm{mg} / \mathrm{kg}]$ & $0.4-0.6$ & $\begin{array}{c}0.4 \pm \\
0.4\end{array}$ & - & $\begin{array}{c}0.04- \\
0.8\end{array}$ & - & $0.6-2.7$ & $0.2-0.3$ & - & $\begin{array}{l}0.7 \pm \\
0.2\end{array}$ & - & - & $\begin{array}{l}0.7 \pm \\
0.5\end{array}$ & - & $\begin{array}{c}0.04- \\
9.0\end{array}$ & - & $\begin{array}{c}<0.04- \\
1.8\end{array}$ \\
\hline $\begin{array}{c}\mathrm{K} \\
{[\mathrm{mg} / \mathrm{kg}]}\end{array}$ & - & - & $\begin{array}{c}0.2 \pm \\
0.1\end{array}$ & - & $\begin{array}{r}16,000 \\
\pm 2,900 \\
-17,000 \\
\pm 2,100\end{array}$ & - & - & - & - & - & $\begin{array}{r}500- \\
20,000\end{array}$ & - & - & - & - & - \\
\hline $\mathrm{Mg}[\mathrm{mg} / \mathrm{kg}]$ & - & - & - & - & $\begin{array}{c}12,000 \\
-12,000 \\
\pm 600\end{array}$ & - & - & - & - & - & $\begin{array}{c:}500- \\
20,000\end{array}$ & - & - & - & - & - \\
\hline $\mathrm{Mn}[\mathrm{mg} / \mathrm{kg}]$ & - & - & 947.0 & - & $\begin{array}{c}700 \pm \\
100- \\
1,300 \pm \\
400\end{array}$ & - & - & - & - & - & $\begin{array}{l}100- \\
500\end{array}$ & - & $3,385.0$ & $\begin{array}{c}50.4- \\
14,700\end{array}$ & $1,241.0$ & $\begin{array}{c}6.2- \\
993.0\end{array}$ \\
\hline $\mathrm{Mo}[\mathrm{mg} / \mathrm{kg}]$ & - & - & - & - & $\begin{array}{c}<100 \\
-100 \pm \\
100\end{array}$ & - & - & - & $\begin{array}{c}18.8 \pm \\
3.9\end{array}$ & - & - & - & - & - & - & - \\
\hline $\mathrm{Na}[\mathrm{mg} / \mathrm{kg}]$ & - & - & - & - & $\begin{array}{r}19,000 \\
\pm 2,100 \\
-21,000 \\
\pm 2,500\end{array}$ & - & - & - & - & - & $\begin{array}{r}500- \\
20,000\end{array}$ & - & - & - & - & - \\
\hline $\mathrm{Ni}[\mathrm{mg} / \mathrm{kg}]$ & $\begin{array}{l}45.0- \\
60.0\end{array}$ & - & 47.8 & $\begin{array}{l}21.0- \\
50.0\end{array}$ & 100.0 & $\begin{array}{l}31.0- \\
247.0\end{array}$ & $\begin{array}{c}14.0- \\
15.0\end{array}$ & - & $\begin{array}{c}111.4 \pm \\
33.7\end{array}$ & - & $10-100$ & $\begin{array}{c}176.3 \pm \\
60.7\end{array}$ & 138.0 & $\begin{array}{c}6.4- \\
743.0\end{array}$ & 89.0 & $\begin{array}{c}0.8- \\
340.0\end{array}$ \\
\hline Notes: & $\begin{array}{l}\text { Inform } \\
C \& D \text { - }\end{array}$ & & & & & & & & & & & & & & & \\
\hline
\end{tabular}


were found in the fine fractions by Wolfsberger et al., 2015. Arsenic was determined to come mainly from the waste rather than from the soil cover (Jain et al., 2005).

In general, heavy metals commonly demonstrate high levels of sorption and precipitation; mercury has been predominantly found as resistant to leaching in landfills (Slack et al., 2005). Only trace levels of volatile heavy metals (As and $\mathrm{Hg}$ ) have been detected in landfill gas whereas particulate matter contributes more to the emissions of heavy metals from landfills (Parker, Dottridge, \& Kelly, 2002). Most of the contaminants released from fine fractions can be found in particulate matter (Kaczala et al., 2017); this suggests that they could be removed using physical methods. $\mathrm{Mn}, \mathrm{Cd}$ and $\mathrm{Zn}$ showed low mobility potential under aerobic conditions in the study of Prechthai et al., 2008 as well. Poor solubility of heavy metal containing phases and slow leaching kinetics of heavy metals in water was reported by Kurian et al., 2003, since the heavy metal concentrations in water extract were lower than of leachate.

Results (Gutiérrez-Gutiérrez et al., 2015) indicate that the leachate is not mobilizing vertically critical metals (critical raw materials - CRMs, according to EU's criteria) in the landfill, since no direct relationship between depth and concentration has been reported consistently for these metals. Leaching tests done by Kaczala et al., 2017 on landfill-mined material (particle size $<10 \mathrm{~mm}$ ) for heavy metals such as $\mathrm{Zn}(0.5-0.9 \%), \mathrm{Cu}(0.2-0.6 \%)$ and $\mathrm{Pb}$ (0.9$1.1 \%$ ) have shown low average leaching ratios (leached amount/amount in solid waste matrix). Low leaching ratios for $\mathrm{Cu}(0.2 \%), \mathrm{Zn}(6.1 \%)$ and $\mathrm{Pb}(0.7 \%)$ from under-sieve (< $20 \mathrm{~mm}$ ) residues, prior to landfilling, were obtained by Cossu \& Lai, 2012 as well. However, limit concentrates in the leachate are often very low ( $<1 \mathrm{mg} / \mathrm{kg}$ dry matter) so that even the leaching of few per mil of the total heavy metal content leads to an excess of limit values.

Other studies on landfills have also reported very low leaching of heavy metals out of the landfill compared to the accumulated amount (Baccini, Henseler, Figi, \& Belevi, 1987; Belevi \& Baccini, 1989; Finnveden, 1996; He, Xiao, Shao, Yu, \& Lee, 2006; Øygard, Måge, \& Gjengedal, 2004); where most of the heavy metals were found retained within the waste matrix. Contaminants such as heavy metals will remain in the waste unless leached out (Jain et al., 2005).

Moreover, studies have reported low leaching rates of heavy metals over relatively long periods of time (Esakku, Palanivelu, \& Joseph, 2003; Gould et al., 1990; Kjeldsen et al., 2002; Reinhart \& Basel Al-Yousfi, 1996; Ross, Harries, Revans, Cross, \& NATHANIEL, 2000).

These previous results and experiences suggest that these elements are most likely to be found in the fine fractions even in older landfills and that their relevance for the feasibility of landfill mining should not be overseen.

Nonetheless, the leaching rate of heavy metals in landfill waste can be influenced by several factors. For example, in an open dumpsite, where the oxygen diffusion rate can be high, the conditions for the leaching of heavy metals out of the waste matrix could be favored (Martensson, Aulin, Wahlberg, \& Agren, 1999). The content of organic compounds in landfilled waste considerably influences the mobility of metals; it either tends to increase the sorption of metals and delay their release or promote their mobilization (Gutiérrez-Gutiérrez et al., 2015). So the particular conditions of each site must be carefully assessed as one of the first steps.

Younger landfills show lower concentrations of As, $\mathrm{Cd}, \mathrm{Cr}, \mathrm{Cu}, \mathrm{Hg}, \mathrm{Ni}, \mathrm{Pb}$ and $\mathrm{Zn}$ in the fine fractions than old ones; this can most likely be attributed to an improved initial quality of the fresh MSW over time (Quaghebeur et al., 2013), e.g. due to separate collection of waste electric and electronic equipment (WEE).

Elements like copper, iron, zinc and rare earth metals are being depleted in their primary sources and there is an increasing demand on these elements due to the development of the standard of living (Jani, Marchand, \& Hogland, 2014). As showed by previous studies (Quaghebeur et al., 2013), the fine fractions from landfill-mined waste might contain high concentrations of certain metals, offering attractiveness for feasible material recovery. Special attention should be paid to critical and rare earth metals, as their prices can reach high levels (Bhatnagar et al., 2017). However, the recovery of rare earth metals from landfilled waste could be used as an additional source of revenue sometimes and not as one of the main drivers for LFM, since these metals are used in very specific applications, which were not predominantly disposed of in MSW landfills and, hence, their primary recovery route for recycling might remain to be the separate collection of the products in which they were used.

Rare earth elements (REEs), platinum group metals (PGMs), Li, In, Co and Sb have been identified as high risk of supply shortage and increased impact on the economy (Hislop, 2011 in Gutiérrez-Gutiérrez et al., 2015).

Concentrations of critical metals, such as Co $(11 \mathrm{mg} /$ $\mathrm{kg}), \mathrm{Ga}(2.2 \mathrm{mg} / \mathrm{kg}), \mathrm{Nb}(2.5 \mathrm{mg} / \mathrm{kg}), \mathrm{Ta}(1.2 \mathrm{mg} / \mathrm{kg})$, and W (56 mg/kg); REEs, such as Gd (0.75 mg/kg), Nd (7.26 $\mathrm{mg} / \mathrm{kg}), \operatorname{Pr}(1.9 \mathrm{mg} / \mathrm{kg})$ and $Y(7.85 \mathrm{mg} / \mathrm{kg}) ; P G M s$, such as Pt $(59 \mu \mathrm{g} / \mathrm{kg}), \mathrm{Rh}(0.092 \mu \mathrm{g} / \mathrm{kg})$ and Ru $(0.5 \mu \mathrm{g} / \mathrm{kg}) ; \mathrm{Ag}$ $(5.3 \mathrm{mg} / \mathrm{kg})$ and $\mathrm{Au}(0.4 \mathrm{mg} / \mathrm{kg})$ have been found present in MSW (Morf et al., 2013). Low recycling rates of REEs, $\mathrm{Sb}, \mathrm{In}, \mathrm{Co}$ and Li have been also reported in Graedel et al., 2011. However, the observed concentrations are far below the cut-off grades which are in the range of several wt\% REE oxides, for example (Lehmann, 2014).

Furthermore, the proportion of REEs in the fine fraction reported by Burlakovs, Kriipsalu et al., 2016 between four sites did not present a significant variation; being Ce, $\mathrm{La}, \mathrm{Nd}$ and $\mathrm{Y}$ the elements found in higher amounts with around $35.5 \mathrm{wt} . \%, 19 \mathrm{wt} . \%, 18 \mathrm{wt} . \%$ and $9 \mathrm{wt} . \%$, respectively, with respect to the total REEs amount. $\mathrm{Ce}, \mathrm{Nd}, \mathrm{Li}, \mathrm{Sb}$ and Co were the most abundant metals in the excavated waste reported by Gutiérrez-Gutiérrez et al., 2015 and did not present significant variations between the studied landfills either. Li had the greatest concentration range of all examined critical metals $(11.17-27.66 \mathrm{mg} / \mathrm{kg})$, followed by Co (8.72-14.14 mg/kg), Sb (6.40-15.15 mg/kg) and In (0.04$0.10 \mathrm{mg} / \mathrm{kg}$ ) (Gutiérrez-Gutiérrez et al., 2015). The range concentrations of $\mathrm{Ce}$ and $\mathrm{Nd}$ were $13.85-25.20 \mathrm{mg} / \mathrm{kg}$ and 8.34-11.75 mg/kg, respectively (Gutiérrez-Gutiérrez et al., 2015). Nevertheless, the amounts of $\mathrm{Cu}, \mathrm{Ag}$ and $\mathrm{Au}$ found were highly variable between different sites and the PGMs 
concentrations, except for Pd (0.41-0.77 mg/kg), were found low (Gutiérrez-Gutiérrez et al., 2015).

The recovery of metals (critical metals and other metals such as $\mathrm{Al}, \mathrm{Cu}, \mathrm{Ag}$ and $\mathrm{Au}$ ) together with other materials of value (e.g. recyclables and RDF) may result in a feasible business model for LFM (Gutiérrez-Gutiérrez et al., 2015). According to Van Vossen \& Prent, 2013, an amount of 2.5 vol.\%. metals recovery could reduce the costs of landfill mining about $20 \%$, which could be raised to $30-40 \%$ by future prices rises due to increasing raw materials scarcity. Thus, the potential of the fine fractions as secondary source of important metals is emphasized by the considerable amounts of them that can be found in the fines (Bhatnagar et al., 2017).

\section{CONCLUSIONS}

The results from the previous investigations reveal that around $40-80 \mathrm{wt} . \%$ of the total excavated material out of a landfill correspond to fine fractions. Each landfill site has its own potential regarding LFM or ELFM. Factors such as the age and type of the landfill, as well as its location and operation procedures might have a relevant impact on their content and valorization potential.

According to previous studies the amount of fine particles to be obtained in a LFM project mostly depends on the excavation and processing techniques, the age and type of the waste and the selected cut-off diameter to define a certain particle size as upper limit for the fines fraction.

Fine fractions can be considered as a relevant source of metals and calorific fractions, as well as a fraction suitable for inert and soil-like material recovery. This situation makes their recuperation from landfills interesting; since old landfills are not just a potential source for such elements, but this might also be a decisive factor to achieve economic feasibility in LFM and ELFM projects.

Moisture, organic content and other physico-chemical properties are interrelated parameters of critical relevance, since processing routes and possible end uses for the fine fractions will depend on their quantities to a certain extent.

Drying of the fine fractions could: i) reduce the amount of surface defilements; increasing the quality of the recyclable materials and raising the efficiency of sorting processes, especially for the sensor-based sorting technologies, such as near infrared (NIR) and color recognition (VIS), ii) enable a more efficient and precise particle size classification in the screening and sieving processes, iii) decrease the total amount of material and material flowrate to be processes and, perhaps, transported and iv) raise the calorific value.

The particle size will be a key parameter in LFM and ELFM future investigations for the separation of the fine fractions into exploitable resources and the minimization of the material to, if the case, be sent back to re-landfilling. To achieve this, the fine fractions may be classified into certain particle size ranges, selected according to the results of the material characterization and particle size distribution during the exploration phase of the project, to determine the cut-off diameter size for the fine fractions and enable more efficient material recovery, for different purposes (e.g. recycling and alternative fuel), and recuperation of soil-like and inert materials in the corresponding processing techniques (e.g. density, magnetic and eddy-current separators, among others).

Much care needs to be taken when comparing information between different investigations, since there are many factors, such as characterization conditions and procedures, laboratory analyses and followed standards, age of the waste material, defined particle size for the fines fraction, among others, that might play an important role during their execution and may differ significantly between investigations.

The implementation of different approaches for the material characterization of waste remains to be one of the crucial challenges for the elaboration of comparable and accurate compiled studies.

\section{ACKNOWLEDGEMENTS}

The authors of this review study, which has been elaborated within the framework of the EU Training Network for Resource Recovery through Enhanced Landfill Mining - NEW-MINE, wish to thank the Marie Skłodowska-Curie Actions (MSCA) and the EU Programme for Research and Innovation Horizon 2020 of the European Union for their great support.

This project has received funding from the European Union's EU Framework Programme for Research and Innovation Horizon 2020 under Grant Agreement No 721185.

\section{REFERENCES}

Attal, A., Akunna, J., Camacho, P., Salmon, P., \& Paris, I. (1992). Anaerobic degradation of municipal wastes in landfill. Water Science and Technology, 25(7), 243-253.

Ayuso, M., Hernández, T., García, C., \& Pascual, J. A. (1996). A Comparative Study of the Effect on Barley Growth of Humic Substances Extracted from Municipal Wastes and from Traditional Organic Materials. Journal of the Science of Food and Agriculture, 72(4), 493-500. https://doi.org/10.1002/(SICI)1097-0010(199612)72:4< 493::AID-JSFA687>3.0.C0;2-4.

Baccini, P., Henseler, G., Figi, R., \& Belevi, H. (1987). Water and element balances of municipal solid waste landfills. Waste Management \& Research, 5(4), 483-499. Retrieved from http://www.sciencedirect.com/science/article/pii/S0734242X87800058.

Baky, A., \& Eriksson, O. (2003). Systems analysis of organic waste management in Denmark.

Bäumler, R., \& Kögel-Knabner, I. (2008). Spectroscopic and wet chemical characterization of solid waste organic matter of different age in landfill sites, Southern Germany. Journal of environmental quality, 37(1), 146-153.

Belevi, H., \& Baccini, P. (1989). Long-term behavior of municipal solid waste landfills. Waste Management \& Research, 7(1), 43-56. https://doi.org/10.1016/0734-242X(89)90007-4.

Bhatnagar, A., Kaczala, F., Burlakovs, J., Kriipsalu, M., Hogland, M., \& Hogland, W. (2017). Hunting for valuables from landfills and assessing their market opportunities: A case study with Kudjape landfill in Estonia. Waste Management \& Research, 17, 0734242X1769781. https://doi.org/10.1177/0734242X17697816.

Bockreis, A., \& Knapp, J. (2011). Landfill Mining - Deponien als Rohstoffquelle. Österreichische Wasser- und Abfallwirtschaft, 63(3-4), 70-75. https://doi.org/10.1007/s00506-010-0275-1.

Bookter, T. J., \& Ham, R. K. (1982). Stabilization of solid waste in landfills. J. Environ. Eng. Div.(Am. Soc. Civ. Eng.);(United States), 108.

Bozkurt, S., Moreno, L., \& Neretnieks, I. (1999). Long-term fate of organics in waste deposits and its effect on metal release. Science of The Total Environment, 228(2-3), 135-152. https://doi. org/10.1016/S0048-9697(99)00047-9. 
Bradl, H. (2005). Heavy metals in the environment: Origin, interaction and remediation (Vol. 6): Academic Press.

Burlakovs, J., Kriipsalu, M., Arina, D., Kaczala, F., Ozola, R., Denafas, G.,. Hogland, W. (2016). Metals and rare Earth's elements in landfills: case studies. Proceedings of the Third International Academic Symposium on Enhanced Landfill Mining. 8 - 10 February, 2016. Lisbon, Portugal.

Burlakovs, J., Kaczala, F., Vincevica-Gaile, Z., Rudovica, V., Orupõld, K., Stapkevica, M... . . Hogland, W. (2016). Mobility of Metals and Valorization of Sorted Fine Fraction of Waste After Landfill Excavation. Waste and Biomass Valorization, 7(3), 593-602. https://doi. org/10.1007/s12649-016-9478-4.

Chen, D., Guan, Z., Liu, G., Zhou, G., \& Zhu, T. (2010). Recycling combustibles from aged municipal solid wastes (MSW) to improve fresh MSW incineration in Shanghai: Investigation of necessity and feasibility. Frontiers of Environmental Science \& Engineering in China, 4(2), 235-243. https://doi.org/10.1007/s11783-010-0016-5.

Cossu, R., Motzo, G. M., \& Laudadio, M. (1995). Preliminary study for a landfill mining project in Sardinia. Proceedings Sardinia 1995. Fifth International Waste Management and Landfill Symposium. Oct. 1995. S. Margherita di Pula, Cagliari, Italy, 841-850.

Cossu, R., \& Lai, T. (2012). Washing of waste prior to landfilling. Waste Management, 32(5), 869-878. https://doi.org/10.1016/j.wasman.2011.12.005

Das, K. C., Smith, M. C., Gattie, D. K., \& Hale Boothe, D. D. (2002). Stability and quality of municipal solid waste compost from a landfill aerobic bioreduction process. Advances in Environmental Research, 6(4), 401-409. https://doi.org/10.1016/S1093-0191(01)00066-1.

Esakku, S., Palanivelu, K., \& Joseph, K. (2003). Assessment of heavy metals in a municipal solid waste dumpsite. In Workshop on Sustainable Landfill Management (Vol. 35, pp. 139-145).

Finnveden, G. (1996). Solid waste treatment within the framework of life cycle assessment. The International Journal of Life Cycle Assessment, 1(2), 74-78. https://doi.org/10.1007/BF02978649.

Francois, V., Feuillade, G., Skhiri, N., Lagier, T., \& Matejka, G. (2006). Indicating the parameters of the state of degradation of municipal solid waste. Journal of hazardous materials, 137(2), 1008-1015. https://doi.org/10.1016/j.jhazmat.2006.03.026.

Gould, J. P., Cross, W. H., \& Pohland, F. G. (1990). Factors Influencing Mobility of Toxic Metals in Landfills Operated with Leachate Recycle. In D. W. Tedder \& F. G. Pohland (Eds.), ACS symposium series, 0097-6156: Vol. 422. Emerging technologies in hazardous waste management (Vol. 422, pp. 267-291). Washington, D.C.: American Chemical Society. https://doi.org/10.1021/bk-1990-0422.ch016.

Graedel, T. E., Allwood, J., Birat, J.-P., Buchert, M., Hagelüken, C., Reck B. K., Sonnemann, G. (2011). What do we know about metal recycling rates? Journal of Industrial Ecology, 15(3), 355-366.

Gurijala, K. R., \& Suflita, J. M. (1993). Environmental factors influencing methanogenesis from refuse in landfill samples. Environmental Science \& Technology, 27(6), 1176-1181. https://doi.org/10.1021/ es00043a018.

Gutiérrez-Gutiérrez, S. C., Coulon, F., Jiang, Y., \& Wagland, S. (2015) Rare earth elements and critical metal content of extracted landfilled material and potential recovery opportunities. Waste Management, 42, 128-136. https://doi.org/10.1016/j.wasman.2015.04.024.

Ham, R. K., Norman, M. R. \& Fritschel, P. R. (1993). Chemical Characterization of Fresh Kills Landfill Refuse and Extracts. Journal of Environmental Engineering, 119(6), 1176-1195. https://doi. org/10.1061/(ASCE)0733-9372(1993)119:6(1176).

He, P.-J., Xiao, Z., Shao, L.-M., Yu, J.-Y., \& Lee, D.-J. (2006). In situ distributions and characteristics of heavy metals in full-scale landfill layers. Journal of hazardous materials, 137(3), 1385-1394. https://doi.org/10.1016/j.jhazmat.2006.04.033.

Hislop, H. (2011). Reinventing the wheel: A circular economy for resource security: Green Alliance.

Hogland, W. (2002). Remediation of an Old Landsfill Site: Soil Analysis, Leachate Quality and Gas Production. Environmental Science and Pollution Research, 9(S1), 49-54. https://doi.org/10.1007/ BF02987426.

Hogland, W., Marques, M., \& Nimmermark, S. (2004). Landfill mining and waste characterization: A strategy for remediation of contaminated areas. Journal of Material Cycles and Waste Management, 6(2). https://doi.org/10.1007/s10163-003-0110-x.
Hull, R. M., Krogmann, U., \& Strom, P. F. (2005). Composition and Characteristics of Excavated Materials from a New Jersey Landfill. Journal of Environmental Engineering, 131(3), 478-490. https:// doi.org/10.1061/(ASCE)0733-9372(2005)131:3(478).

Iglesias Jimenez, E., \& Perez Garcia, V. (1992). Relationships between organic carbon and total organic matter in municipal solid wastes and city refuse composts. Bioresource Technology, 41(3), 265272. https://doi.org/10.1016/0960-8524(92)90012-M.

Jain, P., Kim, H., \& Townsend, T. G. (2005). Heavy metal content in soil reclaimed from a municipal solid waste landfill. Waste Management, 25(1), 25-35. https://doi.org/10.1016/j.wasman.2004.08.009.

Jani, Y., Marchand, C., \& Hogland, W. (2014). The Potentional of Plants to Cleanup Metals from an Old Landfill Site. Linnaeus ECO-TECH 14. Kalmar, Sweden. 24-26 November 2014.

Jani, Y., Kaczala, F., Marchand, C., Hogland, M., Kriipsalu, M., Hogland, W., \& Kihl, A. (2016). Characterisation of excavated fine fraction and waste composition from a Swedish landfill. Waste Management \& Research, 34(12), 1292-1299. https://doi. org/10.1177/0734242X16670000.

Jones, K. L., Rees, J. F., \& Grainger, J. M. (1983). Methane generation and microbial activity in a domestic refuse landfill site. European Journal of Applied Microbiology and Biotechnology, 18(4), 242245. https://doi.org/10.1007/BF00501516.

Jones, P. T., Geysen, D., Rossy, A., \& Bienge, K. (2010). Enhanced Landfill Mining (ELFM) and Enhanced Waste Management (EWM) essential components for the transition to Sustainable Materials Management (SMM). Proceedings of the First International Academic Symposium on Enhanced Landfill Mining. 4 - 6 October 2010. Houthalen-Helchteren, Belgium.

Kaartinen, T., Sormunen, K., \& Rintala, J. (2013). Case study on sampling, processing and characterization of landfilled municipal solid waste in the view of landfill mining. Journal of Cleaner Production, 55, 56-66. https://doi.org/10.1016/j.jclepro.2013.02.036.

Kaczala, F., Mehdinejad, M. H., Lääne, A., Orupõld, K., Bhatnagar, A. Kriipsalu, M., \& Hogland, W. (2017). Leaching characteristics of the fine fraction from an excavated landfill: Physico-chemical characterization. Journal of Material Cycles and Waste Management, 19(1), 294-304. https://doi.org/10.1007/s10163-015-0418-3.

Kelly, R. J. (2002). Solid waste biodegradation enhancements and the evaluation of analytical methods used to predict waste stability. Ph.D. Thesis: Environmental Science and Engineering, Faculty of Virginia Polytechnic Institute and State University.

Kjeldsen, P., Barlaz, M. A., Rooker, A. P., Baun, A., Ledin, A., \& Christensen, T. H. (2002). Present and long-term composition of MSW landfill leachate: A review. Critical reviews in environmental science and technology, 32(4), 297-336.

Krook, J., Svensson, N., \& Eklund, M. (2012). Landfill mining: A critical review of two decades of research. Waste Management, 32(3), 513-520. https://doi.org/10.1016/j.wasman.2011.10.015

Kurian, J., Esakku, S., Palanivelu, K., \& Selvam, A. (2003). Studies on landfill mining at solid waste dumpsites in India. Proceedings Sardinia 2003. Ninth International Waste Management and Landfill Symposium. 6 - 10 Oct. 2003. S. Margherita di Pula, Cagliari, Italy, $3,248-255$.

Lehmann, B. (2014). Economic geology of rare-earth elements in 2014 A global perspective. European Geologist, 37, 21-24.

Liebetegger, W. (2015). Landfill Mining - Charakterisierung der Feinund heizwertreichen Fraktion (Masterarbeit). Montanuniversität Leoben, Leoben, Austria.

Martensson, A. M., Aulin, C., Wahlberg, O., \& Agren, S. (1999). Effect of humic substances on the mobility of toxic metals in a mature landfill. Waste Management and Research, 17(4), 296-304. https://doi. org/10.1034/j.1399-3070.1999.00053.x.

Masi, S., Caniani, D., Grieco, E., Lioi, D. S., \& Mancini, I. M. (2014). Assessment of the possible reuse of MSW coming from landfill mining of old open dumpsites. Waste Management, 34(3), 702-710. https://doi.org/10.1016/j.wasman.2013.12.013.

Maul, A., \& Pretz, T. (2016). Landfill Mining from the processing perspective - a view on mass balance and output streams. Proceedings of the Third International Academic Symposium on Enhanced Landfill Mining. 8 - 10 February, 2016. Lisbon, Portugal.

Mehta, R., Barlaz, M. A., Yazdani, R., Augenstein, D., Bryars, M., \& Sinderson, L. (2002). Refuse Decomposition in the Presence and Absence of Leachate Recirculation. Journal of Environmental Engineering, 128(3), 228-236. https://doi.org/10.1061/(ASCE)07339372(2002)128:3(228). 
Miller, W. L., Earle, J. F., \& Townsend, T. G. (1996). Engineering Control and Augmentation of Biological Decomposition at the Solid Waste Landfills. Project Summary. Department of Environmental Engineering and Sciences, University of Florida Gainesville FL, USA.

Mönkäre, T. J., Palmroth, M. R. T., \& Rintala, J. A. (2016). Characterization of fine fraction mined from two Finnish landfills. Waste Management, 47(Pt A), 34-39. https://doi.org/10.1016/j.wasman.2015.02.034

Morf, L. S., Gloor, R., Haag, O., Haupt, M., Skutan, S., Di Lorenzo, F., \& Böni, D. (2013). Precious metals and rare earth elements in municipal solid waste - Sources and fate in a Swiss incineration plant. Waste Management, 33(3), 634-644. https://doi.org/10.1016/j. wasman.2012.09.010.

Münnich, K., Fricke, K., Wanka, S., \& Zeiner, A. (2013). Landfill Mining: A contribution to conservation of natural resources? Proceedings Sardinia 2013. Fourteenth International Waste Management and Landfill Symposium. 30 Sep. - 4 Oct. 2013. S. Margherita di Pula, Cagliari, Italy.

Øygard, J. K., Måge, A., \& Gjengedal, E. (2004). Estimation of the mass-balance of selected metals in four sanitary landfills in Western Norway, with emphasis on the heavy metal content of the deposited waste and the leachate. Water research, 38(12), 28512858. https://doi.org/10.1016/j.watres.2004.03.036

Parker, T., Dottridge, J., \& Kelly, S. (2002). Investigation of the composition and emissions of trace components in landfill gas: R\&D Technical Report P1-438/TR. Bristol, UK: Environment Agency.

Prechthai, T., Padmasri, M., \& Visvanathan, C. (2008). Quality assessment of mined MSW from an open dumpsite for recycling potential. Resources, Conservation and Recycling, 53(1-2), 70-78. https://doi.org/10.1016/j.resconrec.2008.09.002.

Qian, X., Koerner, R. M., \& Gray, D. H. (2002). Geotechnical aspects of landfill design and construction. p. Prentice Hall, 710.

Quaghebeur, M., Laenen, B., Geysen, D., Nielsen, P., Pontikes, Y., van Gerven, T., \& Spooren, J. (2013). Characterization of landfilled materials: screening of the enhanced landfill mining potential. Journal of Cleaner Production, 55, 72-83. https://doi.org/10.1016/j. jclepro.2012.06.012.

Reinhart, D. R. (1993). A review of recent studies on the sources of hazardous compounds emitted from solid waste landfills: A U.S. experience. Waste Management \& Research, 11(3), 257-268.

Reinhart, D. R., \& Basel Al-Yousfi, A. (1996). The impact of leachate recirculation on municipal solid waste landfill operating characteristics. Waste Management \& Research, 14(4), 337-346.

Rettenberger, G. (2009). Zukünftige Nutzung der Deponie als Resourcenquelle. Tagungsband der 11. Münsteraner Abfallwirtschaftstage. 10 - 11 February, 2009. Münster, Germany.

Riber, C., Petersen, C., \& Christensen, T. H. (2009). Chemical composition of material fractions in Danish household waste. Waste Management, 29(4), 1251-1257. https://doi.org/10.1016/j.wasman.2008.09.013

Ross, D., Harries, C., Revans, A., Cross, C., \& NATHANIEL, P. (2000) Long term fate of metals in landfill: a combined experimental and modelling study.

Rotter, V. S., Kost, T., Winkler, J., \& Bilitewski, B. (2004). Material flow analysis of RDF-production processes. Waste Management, 24(10), 1005-1021. https://doi.org/10.1016/j.wasman.2004.07.015.

Savage, G. M., Golueke, C. G., \& Von Stein, E. L. (1993). Landfill mining past and present. BioCycle (USA).
Slack, R. J., Gronow, J. R., \& Voulvoulis, N. (2005). Household hazardous waste in municipal landfills: contaminants in leachate. The Science of the total environment, 337(1-3), 119-137. https://doi. org/10.1016/j.scitotenv.2004.07.002.

Sormunen, K., Laurila, T., \& Rintala, J. (2013). Determination of waste decay rate for a large Finnish landfill by calibrating methane generation models on the basis of methane recovery and emissions. Waste Management \& Research, 31(10), 979-985. https://doi. org/10.1177/0734242X13490980.

Spooren, J., Nielsen, P., Quaghebeur, M., \& Tielemans, Y. (2012). Characterisation study of landfilled materials with a particular focus on the fines and their potential in enhanced landfill mining. 18th greening of industry network conference (GIN2012). Linköping University. 22 - 24 October, 2012. Linköping, Sweden. Retrieved from www.gin2012.se.

Stevenson, F. J. (1994). Humus chemistry: Genesis, composition, reactions: John Wiley \& Sons.

Tabasaran, O., \& Rettenberger, G. (1987). Grundlagen zur Planung von Entgasungsanlagen, Handbuch Müll und Abfall, Kennz. 4547 Lieferung 1/87, E: Schmidt Verlag.

Townsend, T. G., Miller, W. L., Lee, H.-J., \& Earle, J. F. (1996). Acceleration of landfill stabilization using leachate recycle. Journal of Environmental Engineering, 122(4), 263-268.

Landfill Reclamation, US EPA July 1997.

Van Vossen, W. J., \& Prent, O. J. (2011). Feasibility study: Sustainable material and energy recovery from landfills in Europe. Proceedings Sardinia 2011. Thirteenth International Waste Management and andfill Symposium. 3 - 7 Oct. 2011. S. Margherita di Pula, Cagliari, Italy, 247-248

Van Vossen, W. J. \& Prent, O. J. (2013). Feasibility study: Sustainable material and energy recovery from landfills in Europe. ISTANBUL 3W CONGRESS 2013. Istanbul International Solid Waste, Water and Wastewater Congress. 22 - 24 May, 2013. Istanbul, Turkey.

Wang, Y.-S., Byrd, C. S., \& Barlaz, M. A. (1994). Anaerobic biodegradability of cellulose and hemicellulose in excavated refuse samples using a biochemical methane potential assay. Journal of Industrial Microbiology, 13(3), 147-153. https://doi.org/10.1007/ BF01583999.

Wiemer, K., Bartsch, B., \& Schmeisky, H. (2009). Deponien als Rohstofflagerstätten von morgen-Ergebnisse einer hessenweiten Untersuchung. Bio-und Sekundärrohstoffverwertung IV, Witzenhausen-Institut für Abfall Umwelt und Energie $\mathrm{GmbH}$, Witzenhausen, 685-716.

Wolfsberger, T., Aldrian, A., Sarc, R., Hermann, R., Höllen, D., Budischowsky, A.,. . . Pomberger, R. (2015). Landfill mining: Resource potential of Austrian landfills - Evaluation and quality assessment of recovered municipal solid waste by chemical analyses. Waste Management \& Research, 33(11), 962-974. https://doi. org/10.1177/0734242X15600051.

Zhao, Y., Song, L., Huang, R., Song, L., \& Li, X. (2007). Recycling of aged refuse from a closed landfill. Waste Management \& Research, 25(2), 130-138. https://doi.org/10.1177/0734242X07074053.

Zornberg, J. G., Jernigan, B. L., Sanglerat, T. R., \& Cooley, B. H. (1999). Retention of Free Liquids in Landfills Undergoing Vertical Expansion. Journal of Geotechnical and Geoenvironmental Engineering, 125(7), 583-594. https://doi.org/10.1061/(ASCE)1090 0241(1999)125:7(583). 